\title{
Tradycja placów zabaw w Polsce i Europie
}

\author{
Anna Ostrowska-Tryzno, Hanna Nałęcz, \\ Anna Pawlikowska-Piechotka
}

\section{STRESZCZENIE}

W większości miast europejskich aż do XIX w. nie widziano potrzeby przeznaczenia dla dzieci specjalnych terenów do zabawy i wypoczynku. Od czasów antycznych zarówno w ogrodach prywatnych, jak i na terenach publicznych (wokół placów miejskich, świątyń) dzieci mogły bawić się swobodnie. W okresie nowożytnym potrzeba zapewnienia dzieciom i młodzieży odpowiednich warunków do aktywnego wypoczynku, traktowanego zarówno jako codzienna potrzeba wysiłku fizycznego, jak i sposób zagospodarowania świątecznego czasu wolnego w gronie rodziny i rówieśników - jest oczywista od niecałych 200 lat. Badacze przedmiotu nie są zgodni, co do dokładnej daty, jaką można przyjąć dla najstarszego placu zabaw. Najczęściej wskazywane są kolejne dekady XIX w.: w Europie - w Anglii rok 1859, w Niemczech 1860, a w krajach pozaeuropejskich - w USA 1887. Współczesne place zabaw, z jakimi mamy do czynienia na osiedlach naszych miast, znacząco już odbiegły zarówno programowo jak i funkcjonalnie od historycznych, pierwszych placów zabaw. Niemniej chyba warto przypomnieć te tradycje, ponieważ, pomimo niesprzyjających warunków, zarówno w okresie zaborów, w okresie II RP (1918- 1939), jak i trudnych powojennych latach odbudowy ze zniszczeń wojennych polscy architekci i urbaniści, pedagodzy i wychowawcy, lekarze i działacze społeczni przywiązywali dużą wagę do zapewnienia dzieciom odpowiednio urządzonych terenów otwartych do wypoczynku i zabawy. Były to znaczące inicjatywy, nieustępujące osiągnięciom innych krajów europejskich, tworzące tradycję i dorobek, z którego mamy prawo być dumni.

Słowa kluczowe: place zabaw, tradycja placów zabaw, ogrody im. W.E. Rau'a, ogrody jordanowskie

\section{Wprowadzenie}

Współczesne place zabaw, z jakimi mamy do czynienia na osiedlach naszych miast, znacząco już odbiegły zarówno programowo jak i funkcjonalnie od historycznych miejsc dziecięcej rekreacji w przeszłości. Niemniej, jak się wydaje, warto przypomnieć te historyczne tradycje, ponieważ, pomimo niesprzyjających warunków, zarówno w okresie zaborów, w okresie II RP jak i trudnych powojennych latach odbudowy ze zniszczeń wojennych - polscy architekci i urbaniści, pedagodzy i wychowawcy, lekarze i działacze społeczni przywiązywali dużą wagę do zapewnienia dzieciom odpowiednio urządzonych terenów otwartych do wypoczynku i zabawy.

W okresie nowożytnym potrzeba zapewnienia dzieciom i młodzieży odpowiednich warunków do aktywnego wypoczynku, traktowanego zarówno jako codzienna potrzeba wysiłku fizycznego, jak i sposób zagospodarowania świątecznego czasu wolnego w gronie rodziny i rówieśników - jest oczywista od niecałych 200 lat. Badacze przedmiotu nie są zgodni co do dokładnej daty, którą można przyjąć dla najstarszego placu zabaw. Najczęściej 
wskazywane są kolejne dekady XIX w.; w Europie w Anglii (1859) i w Niemczech (1860), a w krajach pozaeuropejskich - w USA (1887). Przesłanką do ich zakładania, tak jak dla parków i zieleńców miejskich, było gwałtowne uprzemysłowienie i towarzyszące temu gęsta zabudowa i przeludnienie miast, w konsekwencji powodujące fatalne warunki sanitarne i środowiskowe [Chmielewski 2002; Frost 1989, 2010; Ostrowski 1975].

Celem artykułu jest prezentacja podstawowych etapów przemian programowych i funkcjonalnych, jakim w XIX i XX w. podlegały place zabaw. Historię powstania i rozwoju terenów rekreacji przeznaczonych dla dzieci, przedstawiono w kontekście zmian w podejściu do zasad projektowania urbanistycznego, w tym terenów zieleni miejskiej oraz ewolucji koncepcji pedagogicznych.

Temat tradycji zakładania placów zabaw dla dzieci w środowisku zurbanizowanym, jest częścią szerszych poszukiwań badawczych autorek, jakim była problematyka uwarunkowań aktywnego wypoczynku dziecka we współczesnym mieście. Projekt był realizowany w Akademii Wychowania Fizycznego Józefa Piłsudskiego w Warszawie we współpracy z Instytutem Matki i Dziecka w Warszawie, na podstawie grantów Ministerstwa Nauki i Szkolnictwa Wyższego.

\section{Tradycje kształtowania placów zabaw dla dzieci do wieku XIX}

W większości miast europejskich aż do XIX w. nie widziano potrzeby przeznaczenia dla dzieci specjalnych terenów do wypoczynku i zabawy w pobliżu miejsca zamieszkania. W okresie starożytnym, w antycznych greckich i rzymskich miastach, dzieci mogły bawić się swobodnie zarówno w ogrodach i sadach prywatnych, jak i na terenach publicznych, wokół placów miejskich i świątyń. Obyczaj ten dotyczył nie tylko Grecji i Rzymu, ale także innych miast basenu Morza Śródziemnego. W rozdziale 8.5 Księgi Zachariasza jest zapis wizji i proroctwa odnoszącego się do przyszłości Jerozolimy, w czasach panowania perskiego króla Dariusza I, panującego w V w. p.n.e.: „A place miasta (Jerozolimy) będą znów pełne chłopców i dziewcząt bawiących się tam” [Pismo Święte 1990, s. 1110], świadczący najwyraźniej o oczywistym obyczaju anektowania przez dzieci, w celu rozmaitych zabaw, placów i ulic tego antycznego miasta. Podobnie było w nowożytnych miastach europejskich. Tysiąc lat później, w okresie średniowiecza i odrodzenia, w europejskich miastach dzieci nadal bawiły się na mniej ruchliwych ulicach i placach, w przydomowych sadach i ogrodach, a także na podmiejskich błoniach.

Na znanym obrazie Pietera Bruegla Starszego "Zabawy dziecięce” z 1560 r., widzimy plac miejski i odchodzące $\mathrm{z}$ niego wąskie ulice, zabudowane po obu stronach jedno lub dwupiętrowymi domami. Na placu i ulicach, w ogródkach przydomowych, ponad setka dzieci w wieku od kilku do kilkunastu lat bawi się na zakurzonych, błotnistych, niewybrukowanych ulicach i placu. Uważny obserwator może doliczyć się ponad 100 gier i zabaw, którymi zajmują się przedstawione na obrazie dzieci, część z nich okazała się ponadczasowa i atrakcyjna także dla dzieci współczesnych: gra w piłkę, w chowanego, huśtawki (ryc. 1). 
Aż do XIX w., w warunkach stosunkowo ekstensywnej zabudowy, szczególnie rozgęszczonej na terenach przedmieść, gdzie przeważała zabudowa 1-2 kondygnacyjna, młodsze miejskie dzieci bawiły się, tak samo jak przedstawione na obrazie Pietera Bruegla: na ulicach, placach miejskich, w najbliższym sąsiedztwie domu - często jednocześnie opiekując się młodszym rodzeństwem, w ogródkach i w sadach, na niezabudowanych parcelach. Starszych dzieci na obrazie Pietera Bruegla pochodzącego z XVI w. nie widzimy, ponieważ aż do początków XX w. dzieci starsze, 12-16 letnie, były zmuszone do podejmowania zajęć zarobkowych.

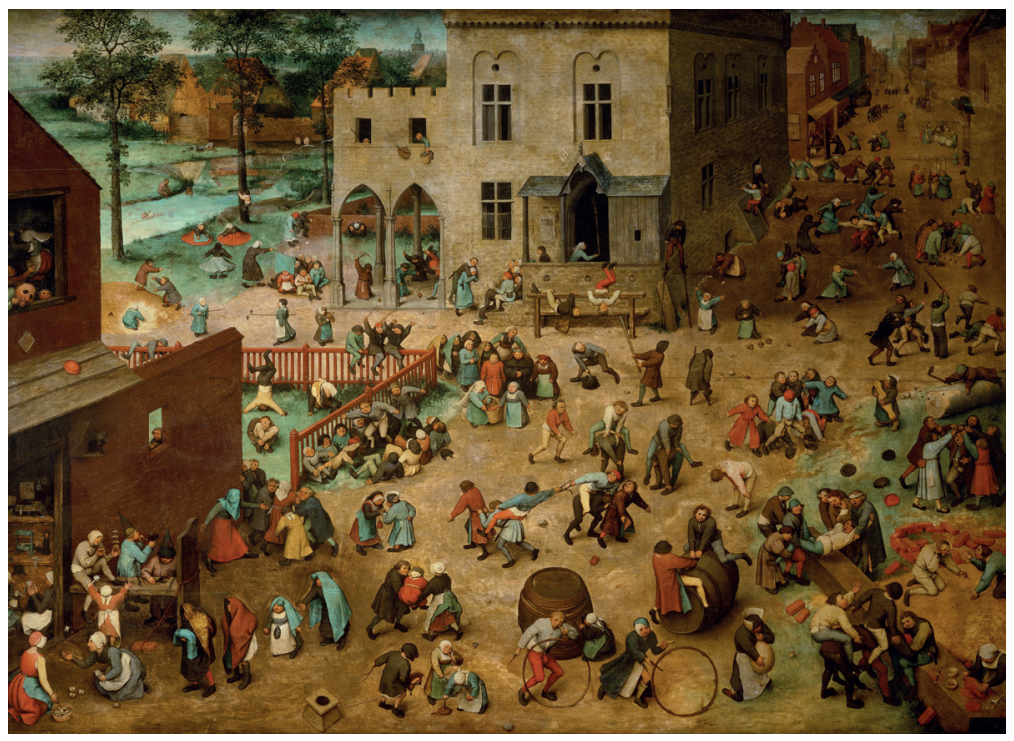

Ryc. 1. Pieter Bruegel Starszy: Zabawy dziecięce (ok. 1560) Można na nim dostrzec kilkadziesiąt różnych gier i zabaw Źródło: Kunsthistorisches Museum Wiedeń, [domena publiczna]

W zdecydowanie uprzywilejowanych warunkach bawiły się i wypoczywały dzieci z warstwy arystokracji, korzystające z prywatnych ogrodów. Począwszy od XVII w. rezydencje magnackie nie tylko podmiejskie, ale również wznoszone w miastach były otoczone rozległymi założeniami parkowymi (np. w Warszawie pałace Krasińskich, Koniecpolskich, Potockich, Lubomirskich) [Pawlikowska-Piechotka 2010, 2011, 2012].

\section{Place zabaw dla dzieci zakładane w XIX w.}

W okresie Oświecenia poczęto dostrzegać szereg wcześniej nieidentyfikowanych problemów społecznych, w tym kwestie koniecznych rewizji programów edukacji, zasad wychowania dzieci, warunków ich aktywnego wypoczynku i zabawy. Z uwagi na postępujące procesy urbanizacyjne, intensywne uprzemysłowienie, gęstniejącą tkankę 
zabudowy i gwałtownie rosnącą populację miast, w końcu XVIII i początkach XIX w. zdawano sobie sprawę z fatalnych warunków sanitarnych, w jakich dzieci bawią się i wypoczywają. W prasie codziennej temat podnosili przede wszystkim pedagodzy i lekarze - w Polsce m.in. zasłużony działacz Komisji Wyznań Religijnych i Oświecenia Publicznego - Stanisław Staszic (1755-1826). Z kolei Jędrzej Śniadecki (1768-1838) jest uważany za prekursora idei powszechnej dostępności terenów sportu i wypoczynku, które to postulaty zawarł w pracy pt. O fizycznym wychowaniu dzieci (wydanej w 1805 r.), dowodząc, że podstawą prawidłowego wychowania dziecka jest równoczesna dbałość o jego rozwój fizyczny i umysłowy, zapewnienie zdrowego środowiska zamieszkania, w tym właściwych warunków do zabawy i wypoczynku.

Za ojca europejskich placów zabaw uznaje się Friedricha Wilhelma Froebla (1782-1852), który przygotował od strony teoretycznej i praktycznie wdrożył program ogrodu dziecięcego dla dzieci najmłodszych (Kindergarten) w założonym przez siebie w $1839 \mathrm{r}$. w Bad Blankenburg (Turyngia) przedszkolu. Wkrótce idea „freblówek”, czyli przedszkoli dla dzieci w wieku 3-6 lat, w których przyjęto nowatorski system wychowania: gry i zabawę, proste ćwiczenia gimnastyczne na terenie otwartym, połączone z nauką przyrody i zajęciami ogrodniczymi - zyskała zwolenników w wielu krajach europejskich, w tym w Polsce. Należy zaznaczyć, że bez wątpienia F.W. Froebl opierał się w swojej nowatorskiej idei wychowania dziecka na pismach szwajcarskiego filozofa epoki Oświecenia - Jean Jacques'a Rousseau (1712-1778), a zwłaszcza jego pracy Emil, czyli o wychowaniu (wydanej w 1761 r.). Warto wspomnieć, że w wielu krajach europejskich, w tym w Polsce, aż do zakończenia II wojny światowej, przedszkola popularnie nazywano właśnie „freblówkami” [Skibniewska i in. 1979]. W konsekwencji dalszych poszukiwań przyjaznego środowiska do wypoczynku i zabawy dzieci, od połowy XIX w. w Europie powstawały przeznaczone dla najmłodszych kąciki zabaw w parkach miejskich. Pierwszym placem zabaw, przy parku miejskim, był prawdopodobnie plac założony w Manchesterze w $1859 \mathrm{r}$.

Jednym z pierwszych ogrodów dziecięcych o różnorodnym programie zajęć sportowoedukacyjnych był ogród w Lipsku, założony ok. 1860 r. Była to inicjatywa koordynowana przez lekarza i działacza społecznego - doktora Gottlieba Schrebera, profesora Uniwersytetu Lipskiego (1808-1861). Park dziecięcy w Lipsku, otwarty w dzielnicy Westvorstadt, był wyposażony w urządzenia do dziś królujące na placach zabaw: piaskownicę, zjeżdżalnię, huśtawki. Ponadto zbudowano pawilon świetlicy, który służył jako stołówka, miejsce zabaw w czasie niepogody, gdzie dzieci spędzały czas na zajęciach zorganizowanych pod kierunkiem wychowawców-instruktorów (ryc. 2). W historycznym miejscu pierwszego europejskiego ogrodu dziecięcego w Lipsku, przy ulicy Aachener Strasse 7, powstało muzeum Deutsches Kleingärtnermuseum [Pawlikowska-Piechotka 2011].

Na wzór Niemiec, w końcu XIX w. i na początku XX, ogrody dziecięce o bogatym programie wychowawczym zakładano także w innych europejskich krajach, w tym w Polsce. Popularyzowanie specjalnie przygotowanych miejsc zabaw dla dzieci na terenach otwartych miasta zawdzięczamy przede wszystkim inicjatywom krakowskiego lekarza i działacza społecznego doktora Henryka Jordana (1842-1907) oraz warszawskiego przemysłowca i filantropa Wilhelma Ellisa Rau'a (1825-1899). Inicjatywa Henryka Jordana 


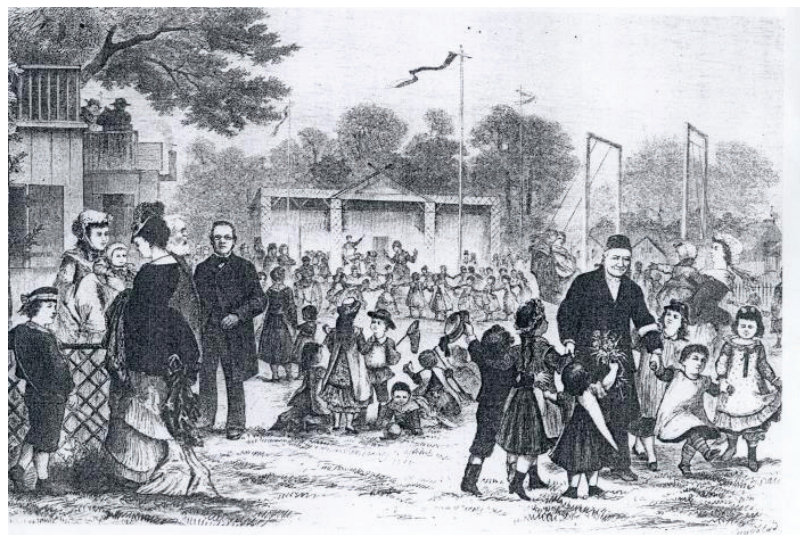

Ryc. 2. Plac zabaw dla dzieci zrealizowany według zasad Daniela Gottlieba Schrebera na terenie jednego z pierwszych w Europie ogrodów działkowych w Lipsku, ok. 1860 (Obecnie muzeum ogrodów działkowych)

Źródło: A. Pawlikowska-Piechotka, 2010

była znakomicie rozwijana w okresie II RP w wielu polskich miastach, do roku 1939 powstało około 160 ,jordanków”, a kolejnych 200 było zaplanowanych. Natomiast rozkwit „,ogrodów dziecięcych", powstających dzięki fundacji W. E. Rau'a, przypadł na wcześniejszy okres, już na ostatnie dekady XIX w.

Ogrody dziecięce Rau'a, jak przyjęło się wówczas nazywać te placówki, różniły się od programu ogrodów jordanowskich regionalizacją były zakładane przede wszystkim w zaborze rosyjskim - w Warszawie i po jednym ogrodzie w Płocku, Kaliszu, Lublinie oraz inną podstawą finansowania - wydatkowano na ich zakładanie i utrzymanie tylko środki prywatne. Pierwszy ogród finansowany przez milionową fortunę W.E. Rau'a (współwłaściciela firmy Lilpop, Rau i Loewenstein) powstał w Warszawie przy ulicy Foksal w 1874 r. Kolejnymi, zarządzanymi przez Warszawskie Towarzystwo Higieniczne, były ogrody dziecięce przy Ogrodzie Saskim oraz na Agrykoli. Następne ogrody, m.in. na Pradze przy ulicy św. Floriana, na Woli przy ulicach Kościelnej i Górczewskiej, na Nowym Mieście przy ulicy Nowomiejskiej - powstawały już na początku XX w., po śmierci fundatora w 1899 r., dzięki hojnym zapisom spadkowym. Później zakładane ogrody im. W.E. Rau’a były organizowane na wzór ogrodu w Krakowie - według programu dra Henryka Jordana. O popularności ogrodów im. W.E. Rau'a niech zaświadczy statystyka: w 1907 r. w ogrodzie na Agrykoli, założonym zaledwie w 1901 r., po kilku latach funkcjonowania, na zorganizowane zajęcia (dzieci młodsze, godz. 10.00 - 13.00, dzieci starsze 13.00 - 16.00, młodzież pracująca 16.00 - 20.00) było zapisanych blisko 23 tys. dzieci, opiekowało się nimi kilkanaście osób - wychowawców, instruktorów i pielęgniarki. Poza zajęciami całorocznymi, organizowano także sezonowe: zimą lodowiska, latem naukę pływalnia na wiślanych plażach. Dzieci były bezpłatnie dokarmiane (dostawały drugie śniadania, obiady i podwieczorki), otaczane opieką pedagogiczną oraz lekarska, w tym szczepieniami przeciw chorobom zakaźnym. W okresie letnim organizowano kolonie w podwarszawskich miejscowościach i półkolonie połączone 
z wycieczkami po okolicy. Program ustalała i zajęcia koordynowała dla każdego ogrodu indywidualnie Rada Pedagogiczna Ogrodu. Przed wybuchem II wojny światowej tylko w Warszawie funkcjonowało 12 ogrodów im. W.E. Rau'a (ryc. 3). Część z nich zamknięto w czasie okupacji, a pozostałe zostały zlikwidowane ostatecznie przez nowe władze po zakończeniu II wojny światowej. W ten sposób zakończyła się blisko 70-letnia historia niezwykłego daru wielkiego przemysłowca dla najmłodszych członków społeczeństwa [Mulanowicz 1907; Pawlikowska-Piechotka 2011].

Warto podkreślić, że na wzór parków w Anglii, Francji i w Niemczech, w ostatnich dekadach XIX w. place zabaw zaczęto zakładać także na wygrodzonych działkach w parkach miejskich i na dużych skwerach (Warszawa, Poznań, Grudziądz). Nazywane w Polsce początkowo "dziecińcami”, były traktowane jako element uzupełniający sportowo-rekreacyjne strefy funkcjonalne parków, obok kortów tenisowych, boisk do gry w krokieta, terenów spacerowych. Było to rewolucyjne podejście, zważywszy, że do tego czasu w parkach nie uwzględniano potrzeb rekreacyjnych najmłodszych. Przeciwnie, aż do

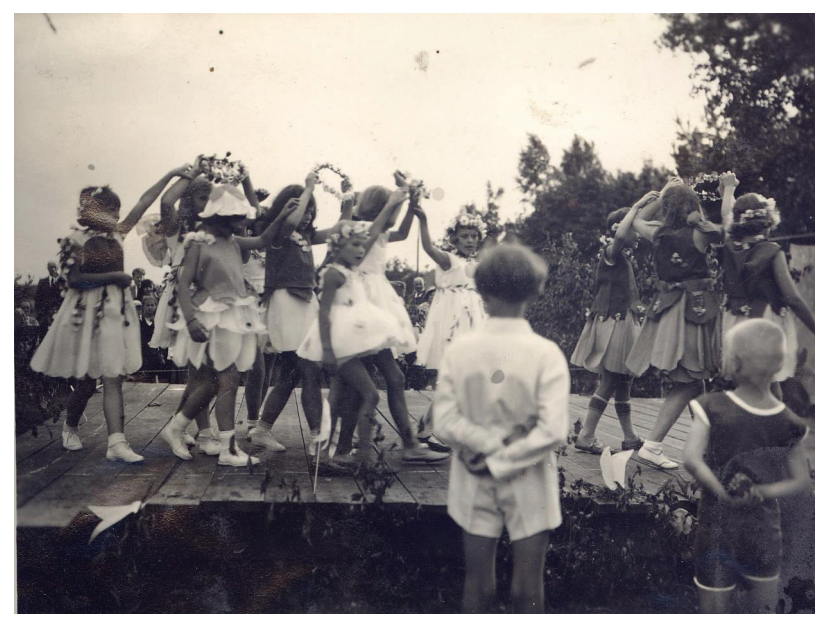

Ryc. 3. Zabawa letnia w Ogrodzie Dziecięcym im. E. Rau'a przy Ogrodzie Saskim w Warszawie, ok. 1930 Źródło: fotografia z albumu rodzinnego autorki

wybuchu I wojny światowej regulamin parków w Europie na ogół wymagał, a groźni stróże rygorystycznie pilnowali, aby dzieci grzecznie spacerowały, nie hałasowały, co najwyżej ostrożnie biegały „,z kółkiem” po żwirowych alejkach. Te surowe zasady obowiązujące przed ponad stu laty w krakowskich parkach wspomina m.in. Krystyna Grzybowska, wnuczka Karola Estreichera, następująco: „[na Plantach] nie można bawić się piłką bo jak upadnie na trawnik nie można po nią pobiec; nie można uganiać się z kółkiem, żeby nie potrącić spacerowiczów" [Grzybowska 1982]. W zbiorach Uniwersytetu Wrocławskiego znajdują się liczne litografie i rysunki z XVIII i XIX w. przedstawiające spacerowiczów w parkach miejskich Berlina, Londynu, Paryża, Wrocławia i w parkach zdrojowych Dolnego Śląska. Możemy na nich dostrzec chłopców w aksamitnych strojach z kołnierzem marynarskim 
i dziewczęta w długich falbaniastych sukienkach, pilnowanych przez bony, mamy i niańki. Te eleganckie dzieci towarzyszące dorosłym, nigdy jednak nie bawią się, nie biegają - jedynie grzecznie spacerują trzymając za rękę opiekunów [Bińkowska 2006].

Pomimo tak korzystnych zmian w uwzględnianiu potrzeb zabaw dziecięcych w parkach miejskich, w dalszym ciągu jednak poważną barierą dostępności do parków miejskich dla niezamożnych dzieci był brak odpowiedniego stroju. Uważano, że przekupnie i biedne dzieci w znoszonych ubrankach mogą razić swoim wyglądem eleganckie towarzystwo. Aż do wybuchu I wojny światowej przed bramą Ogrodu Saskiego był zawieszony napis informujący w językach polskim i rosyjskim, że „Osobom źle ubranym, z paczkami, wstęp wzbroniony". Opisuje wstydliwy problem selekcji spacerowiczów w parkach miejskich Pola Gojawiczyńska w powieści Dziewczęta z Nowolipek "Ciągle się wybierały [do Ogrodu Saskiego], ale przy wejściu stał stójkowy i podobno zawracał z drogi źle ubranych ludzi. Czy one są dość przyzwoicie ubrane? [...] Doszły do bramy od ulicy Żabiej, z drżeniem nóg przeszły obok stójkowego w białych rękawiczkach. Teraz pomknęły śpiesznie - nie zostały zatrzymane" [Gojawiczyńska 1967, s. 56].

Kolejną barierą była znaczna odległość eleganckich śródmiejskich parków od dzielnic robotniczych, w których brakowało terenów zielonych dla dzieci. Następną przeszkodą była konieczność posiadania pieniędzy na odpłatne atrakcje i rozrywki, na przykład na zakup biletu wstępu do welodromu, na wrotowisko lub ślizgawkę organizowaną w parku miejskim zimą. Był to bowiem niebagatelny wydatek nawet kilku rubli w Dolinie Szwajcarskiej, Ogrodzie Saskim, Parku Ujazdowskim lub Łazienkach Królewskich, przerastający najczęściej możliwości dzieci z niezamożnych rodzin.

W Polsce sytuację radykalnie zmieniły dopiero ogrody dziecięce im. W.E. Rau'a oraz ogrody jordanowskie, nieodpłatnie oferujące dzieciom opiekęi rozrywkę, możliwośćuczestniczenia $\mathrm{w}$ zorganizowanych zajęciach na otwartych terenach lub w świetlicy. Niebagatelne znaczenie miała też nowa filozofia podejścia do kształtowania osiedli mieszkaniowych, która zaowocowała specjalnie przygotowanymi terenami rekreacji osiedlowej, ich niezmiernie ważnym składnikiem były specjalnie urządzone place zabaw (z piaskownica, huśtawkami, drewnianymi strukturami przeplotni). Za pierwsze, eksperymentalne pod tym względem, uważa się spółdzielcze osiedla wielorodzinne wznoszone tuż przed wybuchem pierwszej wojny światowej w miastach włoskich i niemieckich. Z tych wzorów czerpali inspirację autorzy osiedli WSM Rakowiec i Żoliborz w Warszawie - powstałych w okresie II RP [Kasprzak, Raszka 2008; Korczak 1919].

\section{Tradycja kształtowania placów zabaw w II RP}

Jeszcze przed wybuchem I wojny światowej w Europie, zrewidowano politykę w odniesieniu do kształtowania zabudowy mieszkaniowej. Prekursorskie osiedla robotnicze, egzemplifikujące zasady nowoczesnego projektowania urbanistycznego, które powstały w Wiedniu („,Czerwony Wiedeń”), Włoszech i przemysłowych miastach Niemiec (Karlsruhe, 
Düsseldorf), były ideologicznym i koncepcyjnym wyzwaniem rzuconym dla XIX-wiecznej gęstej zabudowy osiedli robotniczych z podwórkami-studniami, pozbawionymi terenów zielonych. Integralną częścią nowatorskich rozwiązań było zapewnienie mieszkańcom dostępu do terenów otwartych, urządzonych pod kątem aktywnego wypoczynku: z placami do gier zespołowych, miejscami spokojnego wypoczynku oraz wydzielonymi placami zabaw dla dzieci. Uchwalona w 1933 r. „Karta Ateńska” (podczas IV Kongresu CIAM - Congrès International d'Architecture Moderne), zawierała rekomendacje racjonalnej i zdrowej przestrzeni miasta, z podkreśleniem znaczenia trzech elementów jakie mają zasadniczy wpływ jakość życia: „słońce, przestrzeń, zieleń” [Chmielewski 2002; Ostrowski 1975].

Ogromne znaczenie - dla zapewnienia odpowiednich terenów wypoczynku i zabaw dla dzieci w bezpośrednim sąsiedztwie miejsca zamieszkania - było znane polskim działaczom społecznym, architektom i urbanistom już na początku XX w., jeszcze zanim były możliwości realizacji takich postulatów [Korczak 1919]. Stąd, jako pierwsze, pojawiły się czysto teoretyczne koncepcje planistyczne społecznych osiedli mieszkaniowych z rozległymi terenami wypoczynku, niektóre wysoko nagradzane na międzynarodowych konkursach (np. projekt Warszawskiej Spółdzielni Mieszkaniowej Żoliborz w 1928 r.). Kolejne projekty urbanistyczne „miast ogrodów” gwarantowały $30 \mathrm{~m}^{2}-40 \mathrm{~m}^{2}$ terenów zielonych na 1 mieszkańca (Młociny, Podkowa Leśna, Ząbki, Sadyba). W projektach tych uwzględniano, zgodnie z najnowszymi europejskimi tendencjami, specjalnie urządzone place zabaw dla dzieci.

Warszawska Spółdzielnia Mieszkaniowa (WSM) była przykładem praktycznego wdrażania nowatorskiej zasady organizowania placu zabaw w pobliżu miejsca zamieszkania dziecka: osiedle WSM na Rakowcu (z 1931 r.) miało przewidzianą rezerwę terenu między blokami na zieleń osiedlową i place zabaw (projekt architekci Helena i Szymon Syrkusowie). Na osiedlu WSM na warszawskim Żoliborzu (projekt architekci Barbara i Stanisław Brukalscy) place zabaw dla dzieci powstawały obowiązkowo w każdym zespole „kolonii”, często przy współudziale rodziców i dzieci. W jakim niezwykłym klimacie współpracy społecznej i entuzjazmu powstawały, jak to wyglądało od strony organizacyjnej, opisuje szczegółowo w książce wspomnieniowej Jarosław Abramow-Newerly [Lwy mojego podwórka 2000].

Zakładane na koloniach WSM place zabaw były przestronne, słoneczne, można było do nich dotrzeć bezpośrednio z klatek schodowych, które wychodziły na tereny osiedlowych zieleńców. Było więc bezpiecznie, place zabaw były otoczone ze wszystkich stron blokami mieszkaniowymi, izolowane od ruchu ulicznego, kurzu i hałasu. W programie urządzeń placu zabaw była piaskownica (nazywana wówczas „piaskownikiem”), płytki brodzik i altanka, zieleń drzew i krzewów, trawniki, klomby kwiatowe i ławeczki do wypoczynku [Pawlikowska-Piechotka 2010, 2011, 2012].

W okresie II RP w większych miastach zakładano ogrody dziecięce, opierając się na pomyśle dra Henryka Jordana z końca XIX w. Modelem do naśladownictwa organizacji, funkcji i programu był krakowski Park im. dra Henryka Jordana, założony w 1889 r., na wielohektarowym terenie, wyposażony w świetlicę, stołówkę, halę gimnastyczną altany, labirynty, korty tenisowe, place do ćwiczeń gimnastycznych i boiska do różnych gier zespołowych. Teren był bogato zadrzewiony (posadzono tam 100 tys. drzew), postawiono po- 
mniki. Założeniem parku było zapewnienie dzieciom i młodzieży możliwości wypoczynku w zdrowym, higienicznym środowisku, w otoczeniu zieleni i pod opieką fachowego personelu. Po I wojnie światowej wybudowano tam kąpielisko, kilka dodatkowych boisk, domek dla kucyka oraz górkę saneczkową. W Polsce, po uzyskaniu niepodległości, powstawały kolejne ogrody jordanowskie, przy osobistym wsparciu Józefa Piłsudskiego. W okresie międzywojennym, pomimo trudności gospodarczych i wewnętrznych - przywiązywano ogromną wagę do rozwoju oświaty i wychowania, sportu i prozdrowotnego trybu życia. Częścią tej polityki były projekty szkół wyposażonych w nowoczesne urządzenia sportowe, zieleńce i parki miejskie, ośrodki wypoczynku i sportu w miastach. W latach 1927-1939 powstało $\mathrm{w}$ polskich miastach blisko 160 ogrodów jordanowskich (najwięcej we Lwowie - 12). Przed wybuchem II wojny światowej w Warszawie było 8 ogrodów jordanowskich, o powierzchni od 1,5 ha do 2,0 ha, zlokalizowanych przy ulicach Bagatela (najstarszy ogród), Hożej, Wawelskiej, Opaczewskiej, Ludwiki, Wileńskiej, Wybrzeżu Kościuszkowskim oraz przy WSM Żoliborz. Docelowo planowano założyć w stolicy 54 ogrody jordanowskie dla ponad 204 tys. małych mieszkańców (szacowano chłonność około 4 tys. dzieci na jeden ogród). Miały być równomiernie zlokalizowane w całej przestrzeni miasta, w oddaleniu ok. $1,0 \mathrm{~km}$ jeden od drugiego. Taki rozkład przestrzenny czynił je dostępne pieszym spacerem dla dziecka, umożliwiając codzienny wypoczynek i udział w zajęciach organizowanych (izochrona dojścia szacowana na 10-15 minut). Ogrody jordanowskie w II RP miały bogaty i różnorodny, całoroczny program sportowo-wychowawczy, adresowany do dzieci w wieku 3-14 lat. Dla ich opiekunów organizowano pokazy i prelekcje na tematy wychowawczo pedagogiczne ( $w$ tym psychologia dziecka) oraz zdrowotno-higieniczne (w tym porady na temat zdrowej diety). W ogrodzie jordanowskim przy Wybrzeżu Kościuszkowskim planowano prekursorskie zajęcia gimnastyczne dla młodych matek i towarzyszących im niemowląt. W tym celu wydzielono na terenie ogrodu, już na etapie projektu, część dobrze na-

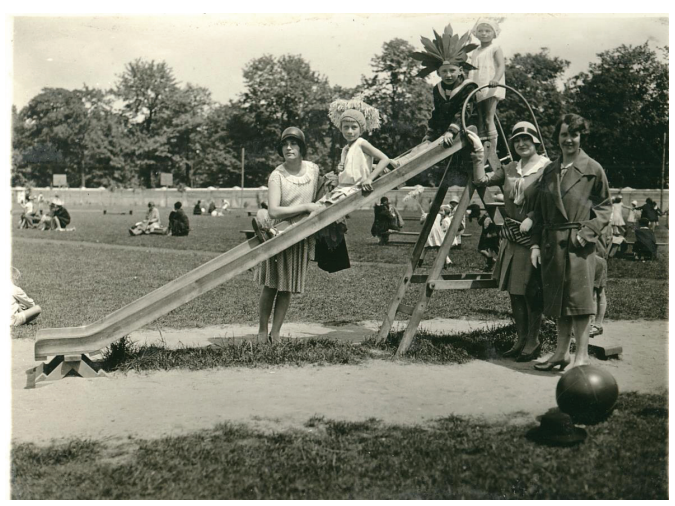
słonecznionego trawnika, w spokojnym i odizolowanym miejscu zespołu. Z uwagi na różnorodną lokalizację (zarówno zamożne Śródmieście, jak i ubogie dzielnice robotnicze), program poszczególnych ogrodów jordanowskich był zróżnicowany. Na przykład w ogrodach na Powiślu, Pradze i Woli rozbudowano segment natrysków, pokojów lekarskich i zabiegowych (przeprowadzano w nich

Ryc. 4. Ogród Jordanowski w Warszawie, przy ul. Bagatela 2/4, otwarty 15 lipca 1929 r., wyposażony w ponadczasowe, jak się wydaje, dla młodszych dzieci atrakcje: piaskownicę, zjeżdżalnię, huśtawki, rozległe trawniki do biegania i wspólnych gier

Źródło: fotografia z archiwum rodzinnego autorki, pochodzi z $1930 \mathrm{r}$. 
okresowe przeglądy stanu zdrowia i szczepiono dzieci) [Wędrowski 1938]. Do wybuchu II wojny światowej, ogrodami jordanowskimi w stolicy zarządzało Warszawskie Towarzystwo Ogrodów Jordanowskich (ryc. 4, 5, 6, 7).

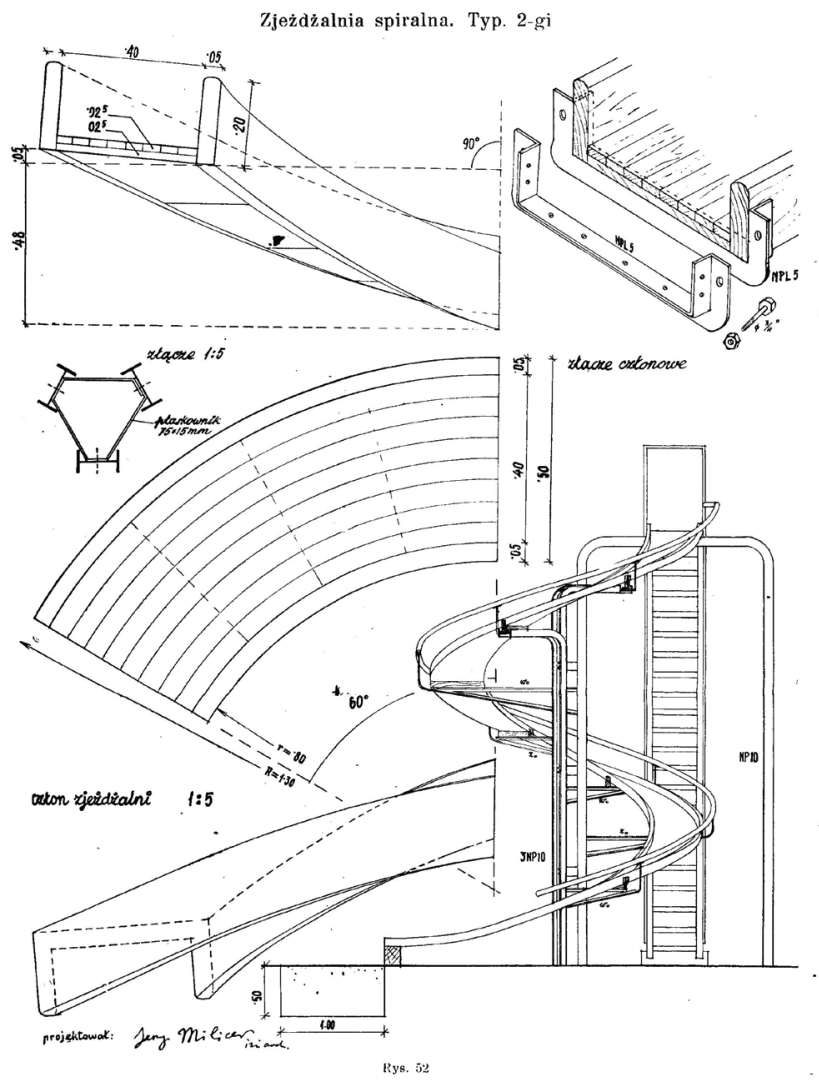

Ryc. 5. Projekt techniczny urządzeń do ogrodu jordanowskiego (proj. inż. K. Wędrowski, ok. 1936)

Źródło: kopia z atlasu „Ogrody Jordanowskie", GKW Warszawa 1938

Egzemplarz ze zbiorów Biblioteki Głównej Akademii Wychowania Fizycznego Józefa Piłsudskiego w Warszawie 
Projekt budynku w ogrodzie jordanowskim przy parku Kościuszki w Katowicach.

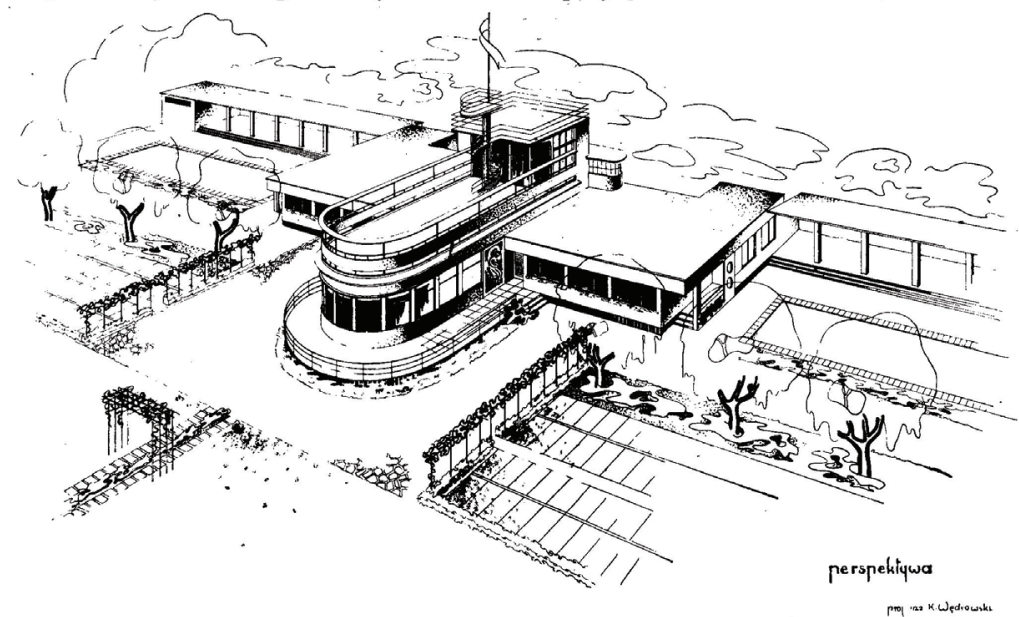

Rys. 91d.

Ryc. 6. Projekt pawilonu głównego (świetlicy) do ogrodu jordanowskiego

przy parku Kościuszki w Katowicach (proj. inż. K. Wędrowski, ok. 1936)

Źródło: kopia z atlasu „Ogrody Jordanowskie”, GKW Warszawa 1938

Egzemplarz ze zbiorów Biblioteki Głównej Akademii Wychowania Fizycznego Józefa Piłsudskiego w Warszawie

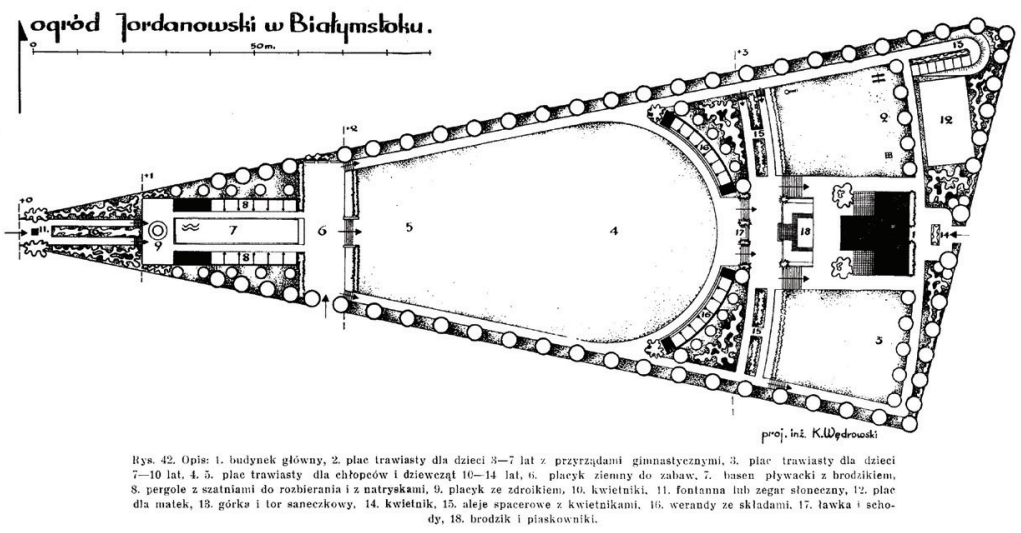

Ryc. 7. Projekt Ogrodu Jordanowskiego w Białymstoku (proj. inż. K. Wędrowski, ok. 1936) Źródło: kopia z atlasu „Ogrody Jordanowskie”, GKW Warszawa 1938

Egzemplarz ze zbiorów Biblioteki Głównej Akademii Wychowania Fizycznego Józefa Piłsudskiego w Warszawie 
Przed wybuchem II wojny światowej były przygotowane dokładne projekty rozwoju ogrodów jordanowskich w Polsce. Planowano założenie do połowy lat 40. po co najmniej jednym ogrodzie w każdym mieście liczącym ponad 30 tys. mieszkańców i po jednym ogrodzie w każdej dzielnicy miejskiej liczącej 10 tys. mieszkańców. W kraju istniało wówczas 160 ogrodów, szacowano potrzebę realizacji ponad 200 kolejnych, aby docelowo uzyskać 400 ogrodów dla dzieci z pełnym programem sportowo-rekreacyjnym i opiekuńczowychowawczym. Za priorytet słusznie uważano zakładanie ogrodów jordanowskich w miastach przemysłowych i dzielnicach robotniczych, gdzie panowały przeludnienie, złe warunki sanitarne, brakowało zieleńców i terenów wypoczynku dla dzieci. Ogrody miały powstawać na terenach należących do gmin, przy wsparciu finansowym, organizacyjnym i programowym ze strony rządowej [Wędrowski 1938]. Ze 160 ogrodów założonych przed 1939 r., działania wojenne przetrwało i w nowych granicach Polski znalazło się zaledwie 41 ogrodów jordanowskich - czyli zaledwie 1/4 zasobów przedwojennych.

W nowej, powojennej rzeczywistości w Polsce, nie było natomiast miejsca dla ogrodów dziecięcych prywatnej Fundacji Rau'a.

Warto też przypomnieć, że dla poprawy warunków środowiska wypoczynku, zabawy i nauki dzieci, od przełomu XIX i XX w., w Polsce i w Europie zakładano ogrody przyszkolne. Ogrody szkolne miały różne funkcje i program, w zależności od regionu Europy, okresu powstania i stopnia nauczania (szkoły podstawowe, średnie, zawodowe), ale zawsze wspólny cel - zapewnić dzieciom zdrowe środowisko do wypoczynku i nauki. W okresie II RP ogrody szkolne powstawały na podstawie regulacji prawnych, nierozerwalnie połączone z budową szkoły i sposobem zagospodarowaniem terenu wokół. W ten sposób zaprojektowano liczne szkoły warszawskie, m.in.: Gimnazjum im. Stefana Batorego (1924), Gimnazjum W. Giżyckiego (1924), Państwowe Gimnazjum im. Emilii Plater (1929), Gimnazjum im. Juliusza Słowackiego (1933) [Dudek-Klimiuk 2019]. Niestety, do czasów nam współczesnych przetrwały jedynie nieliczne historyczne ogrody przyszkolne, a obiekty oświaty obecnie powstające nie przewidują ogrodów w swoim programie.

\section{Tradycja kształtowania placów zabaw w II połowie XX w.}

Po zakończeniu II wojny światowej, wobec potrzeby odbudowy europejskich miast ze zniszczeń wojennych, wskazówkami dla architektów i urbanistów były przede wszystkim rekomendacje „Karty Ateńskiej” (uchwalonej w 1933 r., a opublikowanej 10 lat później, w 1943 r.), akceptowane powszechnie jako manifest nowoczesnej urbanistyki, podporządkowanej trzem fundamentalnym wartościom wyartykułowanym przez Le Corbusiera: słońce, przestrzeń, zieleń. W konsekwencji zespoły mieszkaniowe liczące kilka tysięcy mieszkańców miały zarezerwowane odpowiednio do swojej wielkości tereny pod aktywny wypoczynek i sport, których ważną funkcjonalną częścią były place zabaw dla dzieci. Wielkość i sposób urządzenia osiedlowych terenów zieleni w większości krajów europejskich regulowały przepisy prawa (w Polsce-normy urbanistyczne). W tym duchu powstawały osiedla mieszkaniowe w Polsce, aż do końca XX w. 
Jednakże w tych pierwszych powojennych latach, zanim powstały zorganizowane, osiedlowe place zabaw, polskie dzieci spędzały bardzo często swój czas wolny na pustych, niezabudowanych przestrzeniach miasta, bawiły się w ruinach domów i na placach budowy, wykorzystując wszystko, co mogło zabawie pomóc: pozostawione narzędzia, materiały budowlane, stare meble, wraki maszyn i pojazdów. Do zabawy przydawało się wszystko, co można było w gruzowisku znaleźć (a co nie było potrzebne dorosłym): kawałki cegieł, kamienie, kawałki szkła i metalu, połamane meble. Wszystkie te tajemnicze, bo trudne do zidentyfikowania, części „czegoś” wystarczały do realizacji wymyślonego samodzielnie scenariusza gier, zabawy. Niestety, te zabawy, wśród spalonych konstrukcji grożących zawaleniem, niewypałów lub dopiero wznoszonych, źle zabezpieczonych budowli, kończyły się często poważnymi wypadkami, kalectwem, a nawet śmiercią - o czym donosiła ówczesna prasa codzienna [Pawlikowska-Piechotka 2010, 2011, 2012].

Stopniowo, wraz z odbudową polskich miast po zniszczeniach wojennych, pojawiły się specjalnie dla dzieci zakładane place zabaw przy zespołach mieszkaniowych. Z początku były improwizowane, powstające z inicjatywy społecznej samych mieszkańców, z zastępczych materiałów. W tym czasie ukazywały się nawet poradniki z praktycznymi propozycjami tanich i dostępnych urządzeń terenowych, zasadami organizacji budowy: poczynając od

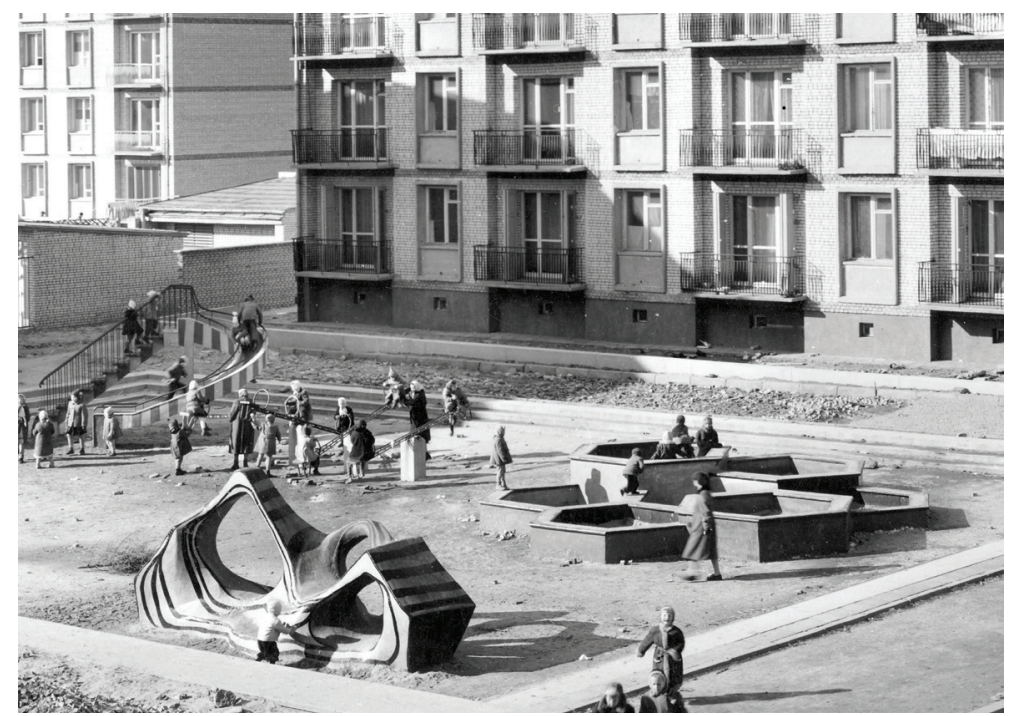

Ryc. 8. Plac zabaw przy ul. Skalbmierskiej w Warszawie, zbudowany wraz z realizacją osiedla mieszkaniowego Bielany I (projekt inż. arch. M. Piechotka i inż. arch. K. Piechotka, 1952-1957) Teren zabaw wyróżniał się na tle innych z powodu niezwykłej różnokolorowej, betonowej rzeźby - przeplotni (projekt artystów plastyków H. i G. Rechowiczów) i nietypowego kształtu piaskownicy. Projekt tego niezwykłego w ówczesnych warunkach placu był efektem prac zespołu architektów i artystów plastyków; niestety z powodu braku środków nie udało się zrealizować pełnego projektu: ani przeplotni zaprojektowanej przez E. Krasińskiego, ani mozaiki autorstwa inż. arch. J. Włodarskiego

Źródło: fotografia z archiwum rodzinnego autorki, pochodzi z 1957 r. 


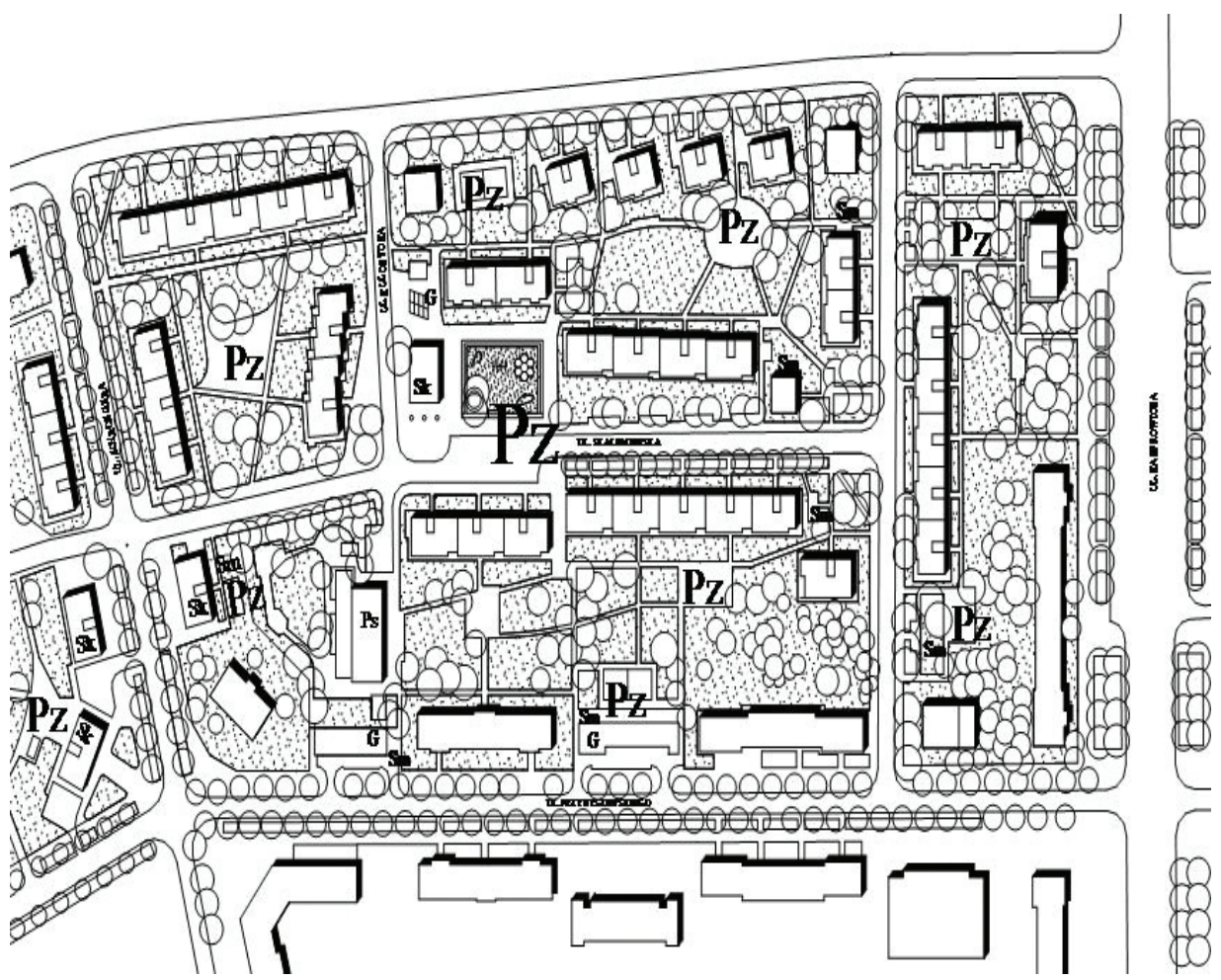

Ryc. 9. Plan osiedla Bielany I

(projekt: inż. arch. M. Piechotka, inż. arch. K. Piechotka, 1952-1957)

W projekcie uwzględniono kilka placów zabaw dziecięcych zlokalizowanych w przestrzeni wewnątrz osiedlowej, tereny zabaw są otoczone 4-kondygnacyjnymi blokami zabudowy wielorodzinnej, izolujące place zabaw przeznaczonych dla dzieci od ruchliwych ulic

Oznaczenia rysunku: PZ - place zabaw, SK - sklepy, SM - śmietniki, G - garaże

Źródło: opracowanie na postawie materiałów archiwalnych inż. arch. Anna Pawlikowska-Piechotka, inż. arch. Maciej Piechotka, 2011

sposobu niwelowania terenu i stawiania ogrodzenia, przygotowania nawierzchni placów gier, po proste przyrządy. Można tam było także znaleźć cenną poradę jak urządzić sezonowe lodowisko, małą skocznię narciarską czy górkę saneczkową. Proponowano budowę domku na kurzej stopce czy osady słowiańskiej z bali, pociągu z rur betonowych pozostałych po jakiejś nieuprzątniętej budowie. Pokazywano, w jaki sposób ze starej łódki przewiezionej na plac zabaw zbudować karawelę-zabawkę, jak z okorowanego pnia zbudować „kozła” do skoków, jak zorganizować bezpieczne kąpielisko na wodach otwartych. Namawiano dorosłych, aby dzieci były angażowane w proces organizacji i budowy - w miarę sił i czasu, aby ich propozycje sposobu urządzenia terenu zabaw były wysłuchane. W poradnikach można było znaleźć praktyczne sugestie organizacji podwórkowych olimpiad i propozycje programu zawodów w takich dyscyplinach, jak: skoki z liny zawieszonej na drzewie, rzucanie lassem, sztafety kolankowe, zmiana koła w rowerze na czas itd. [Jarosiński, Pełka 1968]. 
Po 1972 r. ustawy i normy obligatoryjnie narzucały już nie tylko wielkość, ale i sposób urządzenia placów zabaw na nowo wznoszonych osiedlach mieszkaniowych w całej Polsce [Zarządzenie nr 9 Ministra Gospodarki Terenowej i Ochrony Środowiska z dnia 29 stycznia 1972 r. w sprawie wskaźników i wytycznych urbanistycznych dla terenów mieszkaniowych w miastach. Dziennik Budownictwa 1972, nr 2 poz. 2]. Nie można więc było ani nadmiernie oszczędzać i dla kilkutysięcznego osiedla wygospodarować niewielki tylko teren do rekreacji najmłodszych, ani przeznaczać na zieleń osiedlową więcej terenów niż to przewidywały przepisy. Jeżeli osiedle zajmowało znaczny teren, zalecano zakładanie kilku placów zabaw, aby zachować bezpieczną dla maluchów izochronę dojścia pieszego, nie większą niż $300 \mathrm{~m}$ od mieszkania (5-7 minut) (ryc. 8, 9, 10, 11, 12).

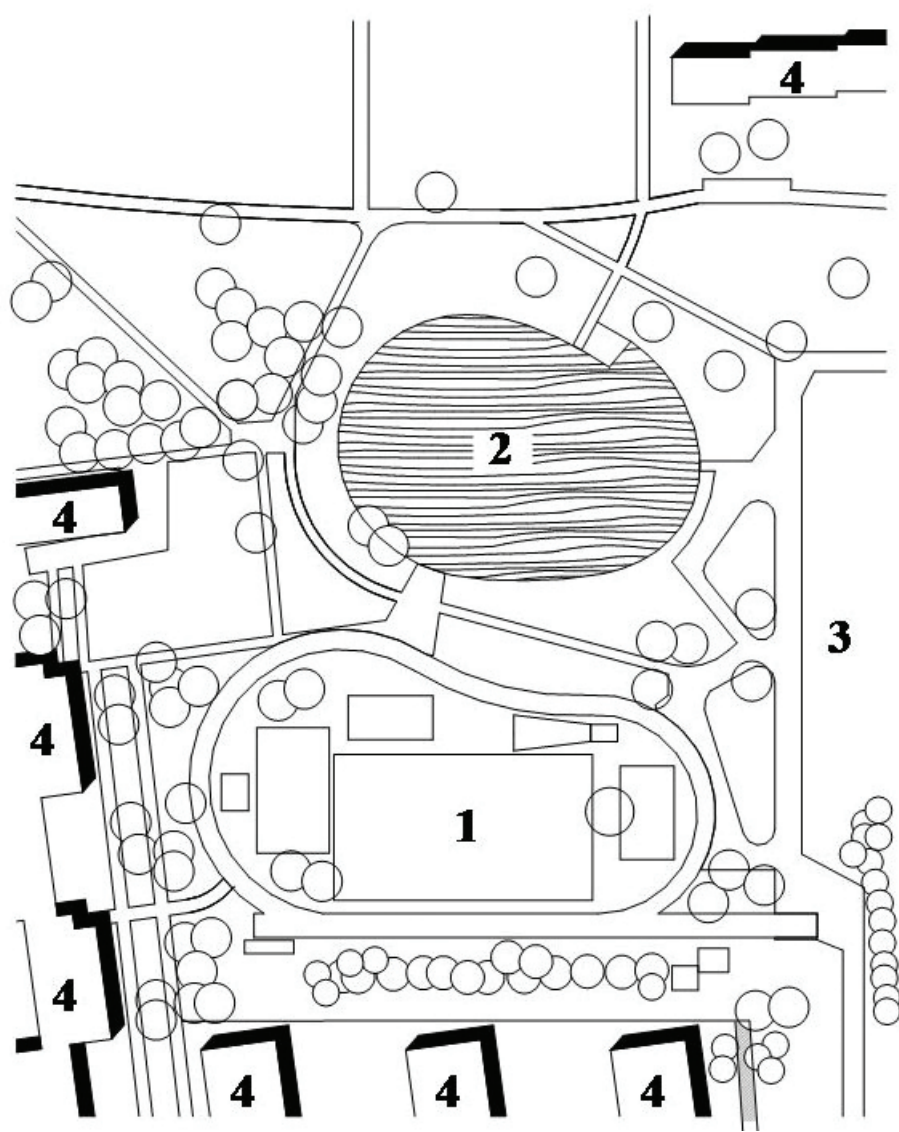

Ryc. 10. Przykład małego parku osiedlowego (osiedle Rakowiec w Warszawie), założonego na 2,5 ha (inż. arch. Z. Malicki, inż. arch. krajobrazu E. Wudzka)

Oznaczenia rysunku: 1 - teren przeznaczony do gier sportowych, 2 - staw dekoracyjny, 3 - ogrody działkowe, 4 - budynki mieszkalne

Źródło: opracowanie na podstawie materiałów archiwalnych inż. arch. A. Pawlikowska-Piechotka; inż. arch. M. Piechotka, 2011 


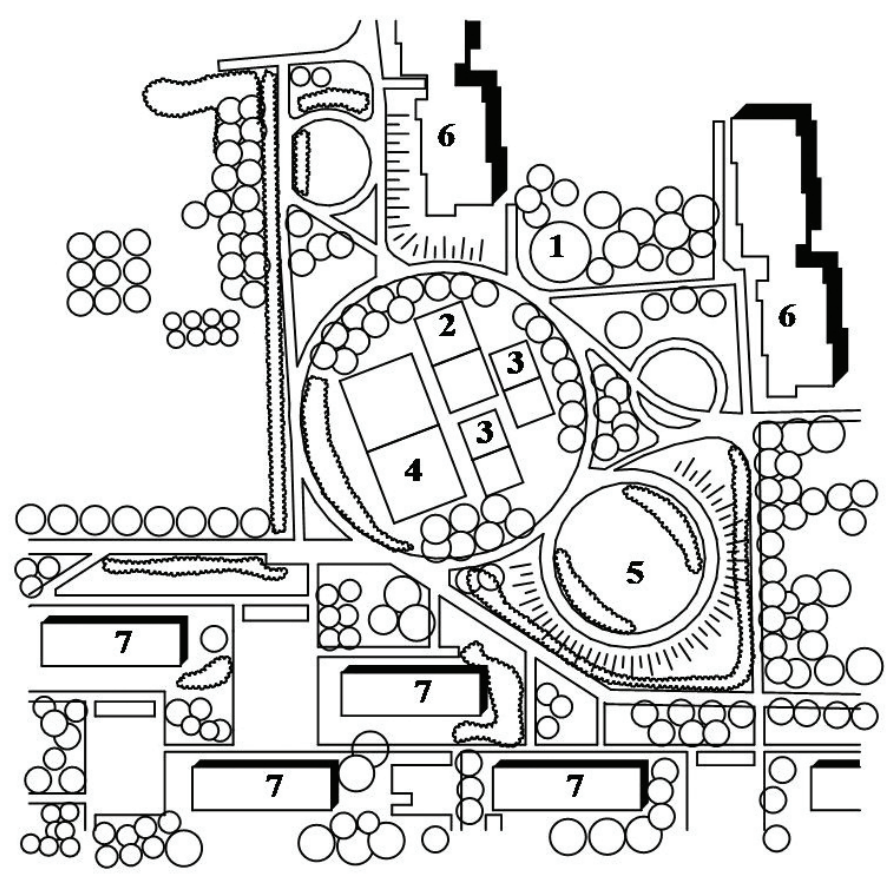

Ryc. 11. Przykład osiedlowego terenu zieleni (osiedle Piaski w Warszawie) przygotowanego z myślą o czynnej i rozwojowej rekreacji dzieci i młodzieży, spokojnym wypoczynku osób starszych. Został zaprojektowany na powierzchni 1,2 ha (inż. arch. J. Nowakowski, inż. arch. krajobrazu B. Kohutnicki) Oznaczenia rysunku: 1- hydrofornia, 2 - boisko do koszykówki, 3 - boisko do siatkówki, 4 - boisko do piłki ręcznej, 5 - plac do gier dla dzieci z górką saneczkową, 6 - budynki wysokie (punktowce o 11 kondygnacjach),

7 - budynki niskie (5 kondygnacji)

Źródło: opracowanie na podstawie materiałów archiwalnych inż. arch. A. Pawlikowska-Piechotka, inż. arch. M. Piechotka, 2011

Program przeciętnego, osiedlowego placu zabaw dla dzieci (komunalnego, zakładowego lub spółdzielczego) przy zabudowie niskiej, 3-4 kondygnacyjnej, był na ogół skromny programowo, ale traktowany zawsze jako integralna część osiedlowego terenu zieleni o powierzchni zazwyczaj około $1000 \mathrm{~m}^{2}$. Z konieczności ograniczeń terenowych przewidywano przede wszystkim urządzenia dla dzieci najmłodszych: piaskownice, huśtawki, przeplotnie, zjeżdżalnie, powierzchnie trawiaste do odpoczynku. Dopiero większy teren (ogrody jordanowskie) pozwalał na bogatszy program, większą rozmaitość urządzeń: boiska do gier dla dzieci starszych, większe struktury przeplotni, górkę saneczkowa, miejsce na zimowe lodowisko. Takie rozwiązanie było z całą pewnością daleko bardziej atrakcyjne dla małych użytkowników, ale mające dwie podstawowe wady: wymagało obszernego terenu i generowało wysokie koszty urządzenia i utrzymania. Stąd, po 1945 r. powstało zaledwie kilkadziesiąt nowych ogrodów jordanowskich, osiągając do końca XX w. - razem z obiektami, które przetrwały - zaledwie połowę stanu sprzed 1939 r. Jednym z nowo założonych był ogród na warszawskim osiedlu Sady Żoliborskie (otwarty ok. 1963 r.), który 
zorganizowano pomimo piętrzonych trudności, dzięki osobistej inicjatywie i nieugiętości projektanta osiedla - prof. Haliny Skibniewskiej (1921-2011) [Skibniewska i in. 1979].

Należy dodać, że ogrody jordanowskie nazywane były wówczas popularnie przez mieszkańców osiedla ,jordankami”, a przez architektów w materiałach planistycznych „robinsonadami”. Było to z jednej strony rozróżnienie mające u podstaw zasadę polityki historycznej PRL wobec osiągnięć II RP (mającą na celu ich dyskwalifikowanie), z drugiej najzupełniej słuszne rozróżnienie, ponieważ program ogrodów powojennych, w stosunku do historycznych założeń, był już mocno okrojony (wyłącznie sportowo-rekreacyjny, bez segmentu opiekuńczo-wychowawczego), brakowało przede wszystkim zorganizowanych zajęć w świetlicy pod kierunkiem wychowawców-instruktorów. Wyjątkiem była w niektórych
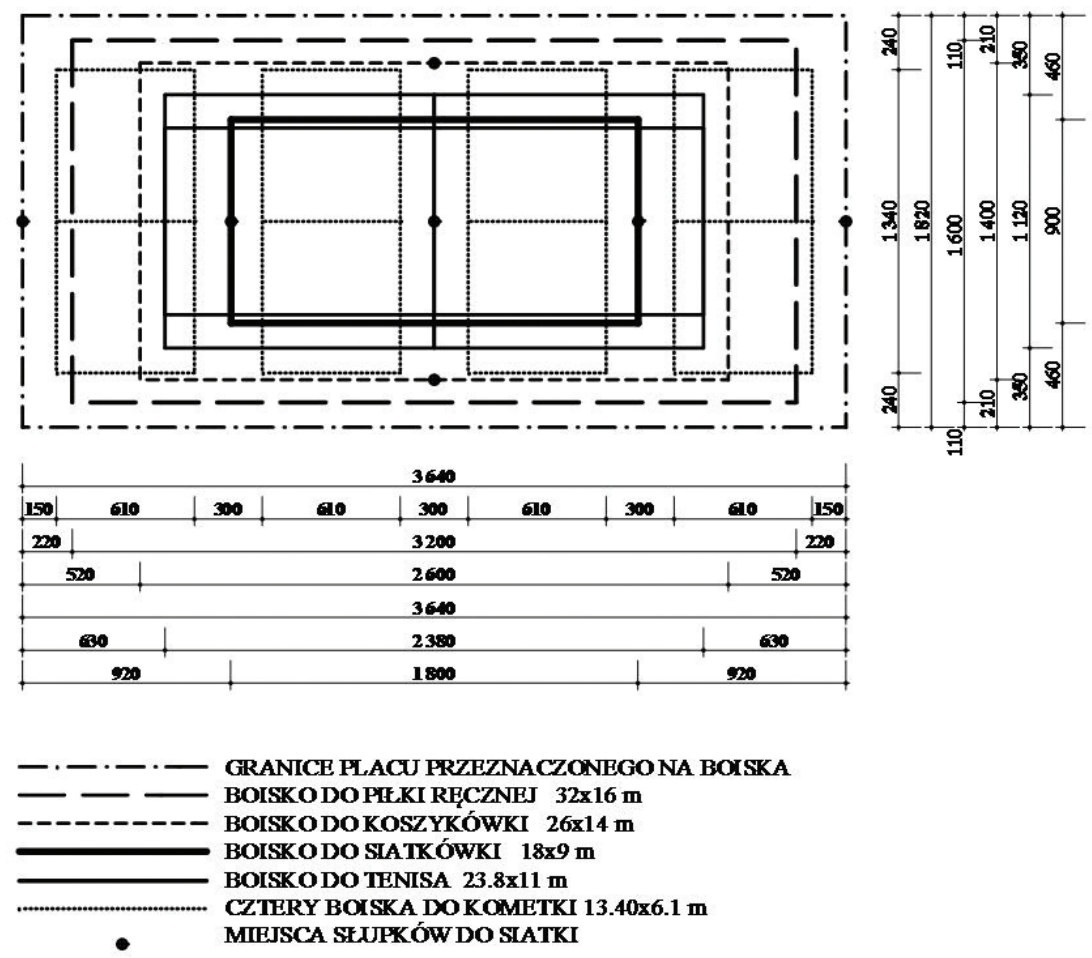

Ryc. 12. Propozycja uniwersalnego boiska na terenie zieleni osiedlowej, przeznaczonego do gier rekreacyjnych dzieci starszych, młodzieży i dorosłych

Dla ułatwienia korzystania, polepszenia orientacji szczególnie młodszych użytkowników zespołu, zaleca się pasy graniczne boisk pomalować za pomocą pastelowych farb, odpornych na wilgoć i ścieranie oraz tym samym kolorem farby wpisać na polu przeznaczenie danego boiska: np. „,Koszykówka” lub innym kolorem „Siatkówka” itp. ${ }^{1}$

Źródło: opracowanie inż. arch. A. Pawlikowska-Piechotka, inż. arch. M. Piechotka, 2011; na postawie danych za: Korzeniewski 1989, Neufert 2002

\footnotetext{
${ }^{1}$ System oznaczeń z powodzeniem stosowany dla oznaczenia boisk różnego przeznaczenia w szkołach stopnia średniego w Wielkiej Brytanii.
} 
obiektach wydzielona część dla tak zwanego „,miasteczka ruchu”, gdzie prowadzono zajęcia edukacyjne praktyczne z zasad ruchu drogowego i można było uzyskać kartę rowerową. Zaletą „robinsonad” była bez wątpienia konsekwentnie utrzymana zasada obszernego terenu, z bogatą zielenią i urozmaiconym programem sportowo-rekreacyjnym, boisk do gier zespołowych, różnorodnych urządzeń do ćwiczeń i zabawek, możliwość wydzielenia stref zabaw adresowanych do dzieci w różnym wieku, a także młodzieży i osób dorosłych - czyli program znacznie wykraczający poza skromne założenia zwykłych osiedlowych placów zabaw wówczas powstających (ryc. 10, 11, 12, 13).

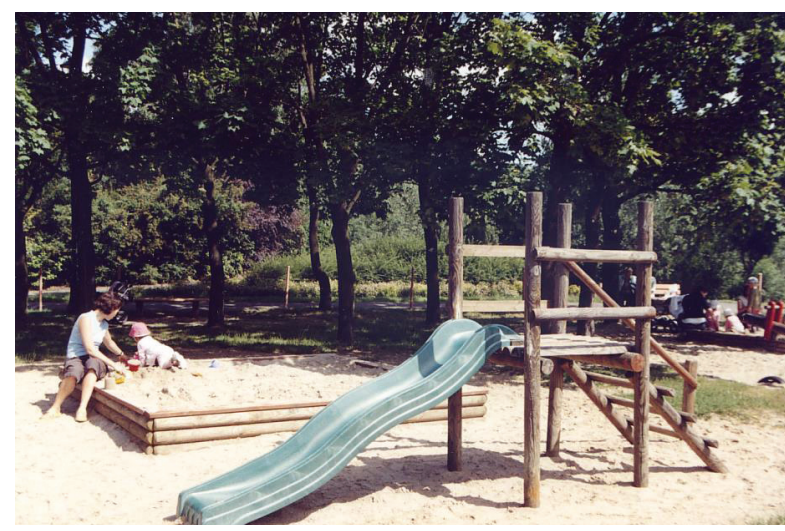

Ryc. 13. Plac zabaw w Ogrodzie Jordanowskim przy ul. Felińskiego w Warszawie (stan z 2008 r., przed modernizacją)

Aż do lat 60. działała tu świetlica, organizująca zajęcia dla dzieci pod opieką wykwalifikowanych wychowawców (była to cenna inicjatywa TPD - Towarzystwa Przyjaciół Dzieci. W pogodne dnie na trawiastym placu, a w czasie niepogody w niewielkim, parterowym budynku, który stał przy ul. Niegolewskiego. Zimą organizowano ślizgawkę, przygotowywano na górce tor do jazdy saneczkami. Obecnie ogród funkcjonuje jako zwykły plac zabaw i skwer miejski, opiekunowie chwalą doskonałą lokalizację, obszerny, ogrodzony, zadbany i silnie zadrzewiony teren, ciszę i spokój, ekologiczne materiały, z których wykonane są zabawki przeznaczone dla dzieci w wieku 3-7 lat. Niestety dla dzieci starszych nie przewidziano ciekawych urządzeń, odpowiednich do zainteresowań tej grupy wiekowej)

Fot. A. Pawlikowska- Piechotka, 2008

Co prawda literatura przedmiotu z opisywanego okresu [Korzeniewski 1979; Kosmala 1979; Piątkowska i in. 1976; Wirszyłł 1986], niezmiennie zalecała tworzenie i urządzanie placów zabaw oddzielnych dla dzieci małych, starszych oraz młodzieży, nie zawsze jednak były takie możliwości terenowe na osiedlach lub środki na realizację zamierzeń. Zapewnienie odpowiednich terenów zabawy dzieciom starszym było szczególnie trudne do rozwiązania w Warszawie i innych dużych miastach Polski, gdzie normatyw urbanistyczny przewidywał bardziej skromną powierzchnię dla terenów sportu i wypoczynku. Bardzo często $\mathrm{w}$ takiej sytuacji zbyt optymistycznie zakładano, że starsze dzieci i młodzież będą korzystać z boisk przyszkolnych, dzielnicowych parków i klubów sportowych. Było to z pewnością racjonalne, ale okazywało się najczęściej założeniem utopijnym, konsekwentnie bojkotowanym przez administrację szkół, która nie życzyła sobie zamieszania, obcych dzieci 
i dorosłych przebywających w obiekcie po zakończeniu zajęć szkolnych [PawlikowskaPiechotka 2010, 2011, 2012].

Tu należy wtrącić, że wśród samych specjalistów nie było wówczas zgodności ani co do kryteriów wyróżniania grup wiekowych, ani jednomyślności względem konieczności strefowania programowo-funkcjonalnego i podziału terenu zabaw na urządzenia odpowiednie dla poszczególnych grup wiekowych [Korzeniowski 1979; Kosmala 1975; Piątkowska i in. 1976]. Nawet ci sami profesjonaliści zmieniali zdanie co kilka lat, w kwestii, w jaki sposób dzielić dzieci na grupy wiekowe, co dowodzi, że kwestia ta była (a raczej jest stale) kontrowersyjna, a kryteria zmieniają się w zależności od propozycji pedagogów, zależą od szczegółów organizacyjnych kolejnych reform edukacji. Poza tym, istniało i nadal istnieje liczne grono specjalistów uważających, że bardziej naturalne i korzystne dla integracji (a w kolejnym etapie - inkluzyjności) społeczności osiedlowej jest zakładanie jednego, uniwersalnego placu zabaw, wspólnego dla dzieci w różnym wieku, młodzieży i osób dorosłych, ale uwzględniającego różnorodne potrzeby trzech generacji użytkowników o różnych zainteresowaniach i stopniu sprawności fizycznej [Skibniewska i in. 1979; Wirszyłło 1986; Woolley 2003, 2012; Woolley, Lowe 2013; Woolley, Griffin 2015]. Również samo urządzenie przestrzeni otwartej sportu i rekreacji dla dziecka, szczegółowy projekt funkcji i programu, wybór odpowiednich przyrządów gimnastycznych i zabawek - nie miało jednoznacznej odpowiedzi w 2. połowie XX w. i jest nadal zagadnieniem otwartym. Bez wątpienia jest jednocześnie problemem kluczowym, bowiem sposób urządzenia placu zabaw może albo hamować, albo zachęcać do zabawy; może albo osłabić bezpieczeństwo użytkowników, albo je wzmocnić. Może więc warto przypomnieć ogólne wymagania, jakie wyróżniano w opisywanym okresie, wobec programu i sposobu urządzenia terenów rekreacji dziecka, aby najpełniej odpowiadał różnorodnym potrzebom i możliwościom dzieci na danym etapie rozwoju:

- fizycznym (wzrost, waga, masa ciała, siła, zręczność, zwinność, gibkość, skoczność, mobilność);

- $\quad$ emocjonalnym (różny stopień gotowości podjęcia ryzyka, fascynacji sprawdzaniem swoich możliwości przy trudnych i nowych zadaniach, samodzielności i samokontroli);

- $\quad$ społecznym (różne fazy umiejętności wchodzenia w relacje z innymi osobami, współpracy w grupie i komunikacji, dążenia do kontaktów towarzyskich, chęci wspólnej zabawy, akceptacji i tolerancji);

- poznawczo-intelektualnym (ciekawość, chęć ponoszenia ryzyka, umiejętności podejmowania trafnych decyzji, oceny uwarunkowań, kreatywność, różny poziom współdziałania zmysłów, w tym integracji sensorycznej, różne możliwości przyswajania wiedzy i umiejętności). 


\section{Podsumowanie i dyskusja}

Wiek XX przyniósł rewolucyjne zmiany w filozofii planowania miast, co miało odzwierciedlenie w podejściu do koncepcji publicznych terenów zieleni. Autorzy „Karty Ateńskiej” mieli wizję modelowego osiedla mieszkaniowego w postaci parku, w którym stoją swobodnie rozmieszczone wielorodzinne bloki mieszkalne. Aby te postulaty realizować, w 2. połowie $\mathrm{XX}$ w. wprowadzono $\mathrm{w}$ wielu krajach europejskich, $\mathrm{w}$ tym w Polsce, regulacje prawne, nakazujące zachowanie rezerw terenu pod zieleń urządzoną przy zespołach mieszkaniowych, przy placówkach oświaty, sportu i wypoczynku, kultury i zdrowia - mające razem z parkami miejskimi tworzyć system zieleni miejskiej, różniące się odpowiednio wielkością, funkcją i programem (ryc. 14, 15).
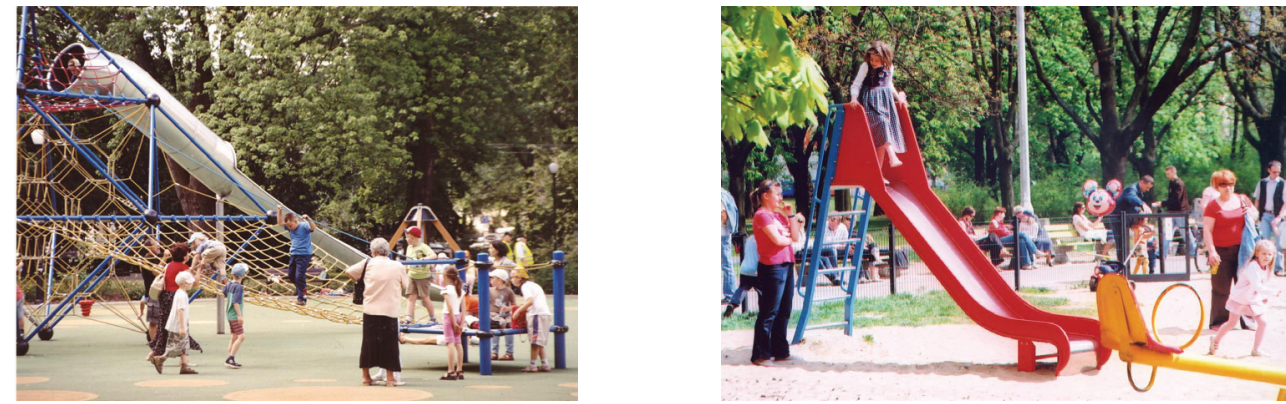

Ryc. 14. Plac zabaw w Parku Żeromskiego w Warszawie (park miejski założony w 1932 r., stan z 2008 r.)

Wielką zaletą tego terenu zabaw jest rozbudowany program funkcjonalny, przewidujący zabawki zarówno dla dzieci starszych, jak pająk do wspinaczki i wysoki ześlizg (widoczne po lewej stronie), jak i dla młodszych - niski kręciołek-karuzela (po prawej strony zdjęcia)

Ryc. 15. Plac zabaw w Parku Praskim w Warszawie jest bardzo popularny, uznany za jeden z najlepszych w tej dzielnicy (park miejski założony w 1871 r., stan z 2008 r.)

Ponad stuletni park miejski jest przez kolejne pokolenia mieszkańców warszawskiej Pragi uznany za doskonale przygotowane miejsce wypoczynku. Plac zabaw poddany niedawno zabiegom rewitalizacyjnym cieszy się wielkim powodzeniem, szczególnie w dni świąteczne i wolne od pracy. Ten przykład placu zabaw dowodzi, że nie ma chyba jednej recepty na rozwiązanie wszystkich zagadnień związanych z właściwą lokalizacją, projektowaniem i urządzeniem miejsc wypoczynku i zabawy dzieci, gwarantujących, aby były bezpieczne, zapewniały dobrą zabawę, były inspirujące, stymulowały rozwój fizyczny i psychiczny dziecka - pomagając kreować szczęśliwe dzieciństwo, a jednocześnie przygotowując do przyszłego współżycia społecznego. Pozostaje stale szukać, eksperymentować i bacznie obserwować dzieci jak się czują na nowych placach zabaw, które zabawki są popularne, atrakcyjne i bezpieczne, a które - ignorowane, omijane przez dzieci, ulegające dewastacji

Fot. A. Pawlikowska- Piechotka, 2008

Obecnie w Polsce nie obowiązują żadne normatywy powierzchni dla miejskich terenów sportu i rekreacji, poza lakonicznym zapisem w regulacjach prawnych, że należy na osiedlu mieszkaniowym zapewnić rezerwę terenu na urządzenie placu zabaw dla dzieci. W odniesieniu do terenów sportu i wypoczynku, w tym do placów zabaw, obowiązują 
natomiast standardy sanitarne oraz normy bezpieczeństwa dla urządzeń i podłoża. Ponieważ rzadko istnieją możliwości wygospodarowania na nowo powstających miejskich osiedlach obszernych terenów zielonych, w ciasnej przestrzeni między blokowej na $30 \mathrm{~m}^{2}-60 \mathrm{~m}^{2}$ mieści się przeważnie tylko skromny program placu zabaw dla dzieci najmłodszych z typowym „kombajnem” z kolorowych materiałów syntetycznych, postawionym najczęściej na syntetycznej wykładzinie imitującej trawę. Nie jest też lepiej na osiedlach powstałych w poprzednich dekadach, ponieważ tereny zielone, o pierwotnej funkcji wypoczynkowosportowej są traktowane jako rezerwa terenowa, sprzedawane przez właścicieli (spółdzielnie lub samorząd terytorialny) jako działki inwestycyjne pod realizacje komercyjnej zabudowy mieszkaniowej.

Niechaj jako przykład zmian w kierunkach kształtowania przestrzeni publicznej, niekorzystnych społecznie i krzywdzących z punktu widzenia ekologii miasta, posłużą tylko dane dotyczące ogrodów jordanowskich. Przed wybuchem II wojny światowej było w Polsce 160 ogrodów jordanowskich, spełniających ważne zadania zdrowotno-rekreacyjne i opiekuńczo-wychowawcze; działania wojenne przetrwało i w nowych granicach kraju znalazło się 41 ogrodów; w latach powojennych 1945-1990 kontynuowano ideę zakładania , jordanków” i w roku 1990 r. było w Polsce 100 ogrodów. Natomiast obecnie szacuje się, że przetrwało jedynie około 20 ogrodów jordanowskich, najczęściej w formie „parków dziecięcych” (na przykład park przy ulicy Felińskiego w Warszawie), okrojonych z pierwotnego rozbudowanego programu wychowawczo-zdrowotnego, jaki cechował ogrody jordanowskie do późnych lat 50. Niestety, możemy tylko z nostalgią wspominać plany z okresu II RP docelowo funkcjonowania w Polsce kilkuset (prawie 400) obszernych terenowo, o bogatym programie funkcjonalnym i wychowawczym, ogrodów jordanowskich.

Poza świadomością istotnej straty, w wymiarze społecznym, wychowawczym i ekologicznym, zaprzepaszczenia tak znakomitego dorobku: blisko 70-letniej tradycji ogrodów dziecięcych im. W.E. Rau'a oraz ponad 100-letniej tradycji ogrodów jordanowskich - pojawia się pytanie: czy i w jakim stopniu można by do tych ideałów powrócić, czy można obecnie powielać, sprawdzone w XX wieku pod względem programowym i funkcjonalnym rozwiązania dla terenów rekreacji dzieci i młodzieży? Byłoby to chyba trudne i nierozsądne, ponieważ zmieniły się znacząco zarówno uwarunkowania prawne, oczekiwania społeczne, jak i możliwości realizacji obszernych terenowo ogrodów dziecięcych. Nawet, jeżeli program historycznych ogrodów jordanowskich byłby zmodyfikowany i dostosowany do współczesnych potrzeb i oczekiwań, to ich zakładanie w tak masowej skali jak to miało miejsce w II RP i pierwszych dekadach PRL - wydaje się obecnie mało realne. Przede wszystkim z uwagi na wysokie koszty zakupu terenów w miastach i wysokie koszty utrzymania niekomercyjnych ogrodów dziecięcych o tak bogatym i różnorodnym programie, wymagającym zatrudnienia wychowawców-instruktorów i pielęgniarek. Musimy niestety założyć, że w najbliższej przyszłości stać będzie na takie rozwiązanie tylko nieliczne zamożne gminy.

Atrakcyjność rozległych terenów zieleni przeznaczonych na wypoczynek i zabawę została z konieczności zastąpiona we współczesnych miastach atrakcyjnymi zabawkami i wymyślnymi urządzeniami stłoczonymi na mniejszej działce. Przy czym należy podkreślić, 
że urządzenie placów zabaw zostało wzbogacone o zabawki uprzednio nieznane i niestosowane: mini górki do wspinaczki z tworzyw sztucznych, pająki z lin i linowe tunele, przeplotnie w formie fantazyjnych figur lub rzeźb, wiszące mostki; o zabawki edukacyjne - inspirujące muzycznie i optycznie. Ponadto na współczesnym placu zabaw mamy coraz częściej urządzenia i zabawki pozwalające na integrację i inkluzję niepełnosprawnych dzieci i niepełnosprawnych opiekunów - w przeszłości problem nawet nierozważany teoretycznie.

Argumentem przeciw mechanicznemu kopiowaniu rozwiązań z przeszłości są nie tylko zbyt głębokie zmiany ekonomiczne i społeczne, wynikające ze zmian ustrojowych państwa. Nie możemy także zapominać o istotnych zmianach klimatycznych, których doświadczamy w ostatniej dekadzie, mających coraz bardziej znaczący wpływ na program i sposób urządzenia miejskiej przestrzeni publicznej, w tym na zasady planowania placów zabaw i ogrodów dziecięcych. Bezśnieżne zimy i przewaga dodatnich temperatur w tym okresie stawiają pod znakiem zapytania zasadność budowy górek saneczkowych i rezerwy miejsc dla naturalnych lodowisk. Z kolei upalne miesiące letnie i silna insolacja wymagają budowy osłon przeciwsłonecznych nad urządzeniami zabaw dla dzieci (nad piaskownicami, huśtawkami, przeplotniami) oraz nad miejscami wypoczynku opiekunów. W wielu projektach z okresu II RP i nawet w latach powojennych, pojawiały się w koncepcjach nie tylko ogrodów jordanowskich, ale i miejskich zespołów sportowo-wypoczynkowych, specjalne „trawniki do kąpieli słonecznych" (Ogród Jordanowski na Wybrzeżu Kościuszkowskim w Warszawie proj. inż. Wędrowski, 1938) czy „,tarasy do kąpieli słonecznych” (tereny wypoczynkowe klubów sportowych „Legia” i „,Skra” w Warszawie). Była to w ówczesnych warunkach pożądana odpowiedź i dobra recepta na walkę z powszechną krzywicą i gruźlicą. Dzisiaj raczej chronimy się przed słońcem, szukamy miejsc zacienionych, ponieważ czujemy obawę przed poparzeniami i strach przed czerniakiem skóry.

Kolejny, dawniej nieznany problem, to obawa przed kleszczami, która obecnie wymaga innego, zrewidowanego w stosunku nawet do ostatnich dekad, podejścia do planowania zieleni na placach zabaw.

Ponadto nowe podejścia w organizacji placów zabaw, ich zauważalna ewolucja funkcji i programu, są konsekwencją zarówno wymienionych zmian klimatycznych, społecznoekonomicznych, jak i postępu w dziedzinie technologii, dostępności nowych, dawniejnieznanych materiałów, dorobku poszukiwań planistów i pedagogów w znoszeniu barier dostępności, a także nowych oczekiwań użytkowników, w tym kaprysów mody. Coraz powszechniej doświadczane zmiany naszego stylu i tempa życia, są widoczne także w sposobie wypoczynku i wyborze codziennych form aktywnej rekreacji na terenach miejskich osiedli mieszkaniowych. Tak jak oczekujemy coraz wyższych standardów naszego środowiska zamieszkania, usług w dziedzinie zdrowia, oświaty, handlu - mamy także coraz bardziej sprecyzowane oczekiwania w stosunku do terenów wypoczynku i sportu w pobliżu miejsca, w którym mieszkamy, w tym do placów zabaw dla dzieci. Tymi też tendencjami, jak się wydaje, należy tłumaczyć nie tylko obserwowany obecnie fenomen popularności tematycznych, ale komercyjnych - co należy podkreślić, ogrodów familijnych zwanych „,rodzinnymi parkami rozrywki”, ale także ponowne odkrycie ponadczasowych zalet naturalnych, bogato zadrzewionych wielohektarowych „parków dziecięcych". 
Zatem pytanie, jakie możemy wysunąć wnioski, ważne dla zadań współczesnych, z doświadczeń prawie 200 lat kształtowania przestrzeni rekreacji dla dzieci - pozostaje bez jednoznacznej odpowiedzi. Wydaje się natomiast, że niezmienne powinny pozostać trzy fundamentalne zasady projektowe, wyartykułowane przez architektów i pedagogów, bioracych udział $\mathrm{w}$ pracach nad kształtem formuły ogrodów jordanowskich w okresie II RP, które projektanci placów zabaw i ich administratorzy powinni brać zawsze pod uwagę [Wędrowski 1938]:

- pożądany jest podział placu zabaw na strefy funkcjonalne (wiek, możliwości fizyczne i emocjonalne, zainteresowania dziecka) ${ }^{2}$;

- $\quad$ konieczne jest wyposażenie placu zabaw w bezpieczne urządzenia - odpowiednie dla wyróżnionych stref funkcjonalnych - (uwzględniających wiek, możliwości fizyczne, emocjonalne oraz zainteresowania dziecka), stale monitorowanych i bieżąco naprawianych;

- $\quad$ konieczne jest zapewnienie bezpiecznej nawierzchni, łatwej do utrzymania w czystości, amortyzującej upadki i redukującej niebezpieczeństwo urazów, zachowanie bezpiecznej odległości między urządzeniami.

$W$ niniejszym artykule przedstawiono materiat badań projektu statutowego ds.-300 AWF (z lat 2016-2019), na temat tradycji i współczesnych warunków aktywnego wypoczynku dzieci $w$ środowisku zurbanizowanym (jest to kontynuacja projektu ds.-114 AWF z lat 2008-2011). Oba projekty byty realizowane na Akademii Wychowania Fizycznego Józefa Piłsudskiego w Warszawie, przy wspótpracy z Instytutem Matki i Dziecka w Warszawie, na podstawie grantów statutowych Ministerstwa Nauki i Szkolnictwa Wyższego.

\footnotetext{
${ }^{2}$ We współczesnej literaturze przedmiotu, z małymi wyjątkami, w sposób świadomy konsekwentnie pomijane jest kryterium płci dziecka [Rice 2009; Risotto 2012; Sawyer 2009; Woolley 2010]. Autorki pragną jednak podkreślić, że na podstawie przeprowadzonych badań terenowych w ramach ds.-300 AWF w wyborze zabawek zauważalne są wyraźne różnice między chłopcami i dziewczynkami w wieku powyżej 5 lat. Inaczej rzecz się miała w XIX i początkach XX w., kiedy często wyznaczano na placach zabaw strefy funkcjonalne i urządzenia odpowiednio tylko 'dla dziewczynek' i 'dla chłopców' [Gołąb 2014; Wędrowski 1938].
} 


\section{Literatura}

Abramow-Newerly J., 2000, Lwy mojego podwórka, Rosner i Wspólnicy, Warszawa.

Bińkowska I., 2006, Natura i miasto, Wydawnictwo Biblioteki Uniwersytetu Wrocławskiego, Wrocław.

Chmielewski M.J., 2002. Teoria urbanistyki, Wydawnictwo Naukowe Politechniki Warszawskiej, Warszawa.

Dudek-Klimiuk J., 2019, Ogrody szkolne w Polsce międzywojennej, Wydawnictwo Naukowe Semper, Warszawa.

Frost J.L., 1989. Play environment for young children in the USA 1800-1990, Children's Environments Quarterly, 6, 4, s. 17-24.

Frost J.L., 2010, A history of Children's Play and Play Environment, Routledge, New York and London.

Gojawiczyńska P., 1967, Dziewczęta z Nowolipek, Wydawnictwo Iskry, Warszawa.

Grzybowska K., 1982, I ja i Franuś, Nasza Księgarnia, Warszawa.

Gołąb M., 2014, Place zabaw: źródła, ewolucja, działanie, praca magisterska pod kierunkiem prof. Pawła Rodaka, Uniwersytet Warszawski (niepublikowana).

Jarosiński S., Pełka J., 1968, Urzadzenia terenowe dla dzieci, Zakład Wydawnictw CRS, Warszawa.

Kasprzak K., Raszka B., 2008, Miejskie place zabaw - ujęcie historyczne, Nauka, Przyroda, Technologie, 2, 4, s. 1-9.

Korczak J., 1919, Jak kochać dziecko - prawo dziecka do szacunku, reprint wydania z 1919: Wydawnictwo Akademickie „Żak” (2002), Warszawa.

Korzeniewski W., 1989, Budownictwo mieszkaniowe, Wydawnictwo Arkady, Warszawa.

Kosmala M., 1979, Dlaczego place zabaw nie bawia dzieci, Architektura, 375-376, s. 48-60.

Mulanowicz J., 1907, Powstanie i stopniowy rozwój ogrodów im. W.E. Rau'a w Warszawie. Szkic historyczny, Skład i Druk A. Michalskiego, Warszawa.

Nowak Z. 1997, Wymagania i zasady kształtowania integracyjnych placów zabaw dla dzieci przy uwzględnianiu potrzeb dzieci niepetnosprawnych, Centralny Ośrodek Badawczo-Projektowy Budownictwa Ogólnego, Warszawa.

Ostrowski W., 1975, Urbanistyka wspótczesna, Wydawnictwo Arkady, Warszawa.

Pawlikowska-Piechotka A., 2010, Urban Outdoor Recreation: Children's Playgrounds, Studies in Physical Culture and Tourism, 17, 4. University School of Physical Education in Poznań, s. 375-385. 
Pawlikowska-Piechotka A., 2011, Przestrzeń rekreacji dziecka w mieście, Novae Res, Gdynia.

Pawlikowska-Piechotka A., 2012, Europejskie tradycje rekreacji w mieście, Akademia Wychowania Fizycznego Józefa Piłsudskiego, Warszawa.

Piątkowska K., Scholtz A., Wirszyłło R., 1976, Rekreacja w osiedlu, Zakład Wydawnictwa CRS, Warszawa.

Pismo Święte Starego i Nowego Testamentu, 1990, Wydawnictwo Pallotynów, Warszawa.

Pomorski J., Poskrobko W., 1998, Kształtowanie terenów zieleni, Wydawnictwa Szkolne i Pedagogiczne, Warszawa.

Rice L., 2009, Everyday Urbanism and Play, Journal of Planning and Architecture, University of Bristol, Bristol, s. 53-55.

Risotto A., 2012, Projects and Policies for Childhood in Italy [w:] Culture, Environment Action and Sustainability, International Association of People Environment Studies IAPS, Gottingen, s. 203-211.

Rousseau J.J., 2019, Emil, czyli o wychowaniu, Empik Klasyka, ebook.

Sawyer H. Th., 2009, Facilities Planning for Health, Fitness, Physical Activity, Recreation and Sports (12 wydanie), Sagamore Publishing, Urbana (USA).

Skibniewska H., Goryński A., Bożekowska D., 1979, Tereny otwarte w miejskim środowisku mieszkalnym, Wydawnictwo Arkady, Warszawa.

Wędrowski K., 1938, Ogrody jordanowskie i ich typy zastępcze w planach miast $i$ wsi, Centralne Towarzystwo Ogrodów Jordanowskich, Warszawa.

Wirszyłło R., 1986, Obiekty sportowe, Wydawnictwo Arkady, Warszawa.

Woolley H. E., 2003, Urban Open Spaces, Taylor \& Francis, London-New York.

Woolley H.E., 2012, Now Being Social: The Barrier of Designing Outdoor Play Spaces for Disabled Children, Children and Society, 27, 6, s. 448-458.

Woolley H.E., Lowe A., 2013, Exploring the Relationship between Design Approach and Play Value of Outdoor Play Spaces, Landscape Research, 38, 1, s. 53-74.

Woolley H.E., Griffin E., 2015, Decreasing experiences of home range, outdoor spaces, activities and companions: changes across three generations, Children's Geographies, 13, 6, s. 677-691.

Zarządzenie nr 9 Ministra Gospodarki Terenowej i Ochrony Środowiska z dnia 29 stycznia 1972 r. w sprawie wskaźników i wytycznych urbanistycznych dla terenów mieszkaniowych w miastach. Dziennik Budownictwa 1972, nr 2 poz. 2. 


\section{Tradition of child's playgrounds in Poland and Europe}

\section{ABSTRACT}

Until the 19th century, most European cities did not consider the need for creating special areas for children to play and relax as an important issue. Since ancient times children could play freely both in the private gardens and in the public areas (around city squares, temples). In the modern times, the need to provide children and youth with the right conditions for active recreation, treated both as a daily need for physical activities and as a way to spend time with family and peers during festivities, has been evident for less than 200 years. Researchers focused on the subject do not agree on the exact date of the creation of the oldest playground. The following decades of the nineteenth century are indicated most often: in Europe - England (1859), Germany (1860), in the non-European countries - the USA (1887). Contemporary playgrounds, which are present in our urban housing estates, are significantly different from the historic, first playgrounds, both programmatically and functionally. Nevertheless, these traditions seem to be worth recalling. Despite the unfavourable conditions during the Partitions of Poland, the Second Polish Republic (1918-1939) and during difficult post-war years of reconstruction from war damage, Polish architects and urban planners, pedagogues and educators, doctors and social activists attached great importance to providing children with properly designed outdoor areas to rest and play. These were significant initiatives, not inferior to the achievements of other European countries, which shaped the tradition of which we have the right to be proud of.

Key words: playgrounds, tradition and history of playgrounds, Dr Henryk Jordan Gardens, W.E. Rau Children Gardens

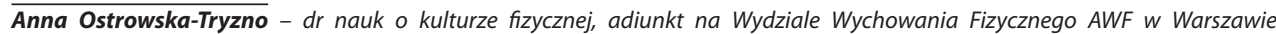
Specjalizuje się w problematyce zrównoważonego rozwoju miast oraz odpowiedzialnej turystyce biznesowej. Aktualnie koncentruje swoją aktywność badawczą na zagadnieniach dotyczących plenerowej infrastruktury sportowo-rekreacyjnej w miastach, dostępnej dla dzieci i młodzieży, osób starszych oraz osób z niepełnosprawnościami.

e-mail:anna.tryzno@awf.edu.pl

Anna Ostrowska-Tryzno - PhD in physical culture, works at the Faculty of Physical Education at the Józef Piłsudski University of Physical Education in Warsaw. She specializes in sustainable urban development and responsible business tourism. She is currently focusing her research activity on issues related to outdoor sports and recreation infrastructure in cities, accessible for children and youth, the elderly and people with disabilities.

e-mail:anna.tryzno@awf.edu.pl
}

Hanna Nałęcz - pedagog, specjalista zdrowia publicznego, dr nauk o kulturze fizycznej; ukończyła studia magisterskie na Wydziale Pedagogiki Uniwersytetu Warszawskiego, studia pierwszego stopnia w dziedzinie zdrowia publicznego w Akademii Medycznej im. K. Marcinkowskiego w Poznaniu (2009), uzyskała stopień doktora nauk o kulturze fizycznej na Wydziale Wychowania Fizycznego Akademii Wychowania Fizycznego w Warszawie (2010). Jest certyfikowanym edukatorem edukacji zdrowotnej i promocji zdrowia MEN (2008), ukończyła ponadto kursy w kierunku edukacji zdrowotnej w kraju i zagranica. Staż naukowy odbyła na Uniwersytecie w Limerick, Irlandia - WydziałEducation \& Health Sciences (2014). Od 2006 r. pracuje w Instytucie Matki iDziecka w Warszawie, obecnie w Zakładzie Zdrowia Dzieci i Młodzieży IMiD. Uczestnik krajowych i międzynarodowych badań, konsultant naukowy w krajowych i międzynarodowych projektach badawczych, ukierunkowanych na aktywność fizyczna dzieci, młodzieży i dorosłych. Jest autorem $i$ współautorem ponad 70 publikacji naukowych krajowych i zagranicznych (w tym w czasopismach z Listy Filadelfijskiej) oraz 
doniesień konferencyjnych, dotyczących aktywności fizycznej, psychospołecznych uwarunkowań zdrowia i zachowań zdrowotnych dzieci, młodzieży i dorosłych.

Kontakt: Instytut Matki i Dziecka, adiunkt w Zakładzie Zdrowia Dzieci i Młodzieży, Warszawa;

e-mail: hanna.nalecz@imid.med

Hanna Natęcz, PhD-teacher, public health specialist, PhD in physical culture sciences; she graduated from the Faculty of Pedagogy at the University of Warsaw, completed the undergraduate studies in Public Health at the Medical Academy K. Marcinkowski in Poznań (2009), obtained a PhD degree in physical culture at the Faculty of Physical Education at the Józef Piłsudski University of Physical Education in Warsaw (2010). She is a certified MEN educator in health education and health promotion (2008), she also completed several courses in health education in Poland and abroad. She took an internship at the University of Limerick, Ireland - Faculty of Education \& Health Sciences (2014). Since 2006 she has been working at the Institute of Mother and Child in Warsaw, currently at the Department of Child and Adolescent Health. Participant of national and international research projects, scientific consultant in national and international research projects focused on physical activity of children, youth and adults. She is the author and co-author of over 70 scientific publications (including journals listed on ISI Master Journal List) and conference reports on physical activity, psychosocial determinants of health and health behaviours of children, youth and adults published in Poland and abroad.

Contact: Institute of Mother and Child, assistant professor at the Department of Child and Adolescent Health, Warsaw; e-mail: hanna.nalecz@imid.med

Anna Pawlikowska-Piechotka, prof. dr hab. inż. arch. - architekt i urbanista, w latach 2004- 2014 profesor wizytujący na University College Birmingham (Wielka Brytania), Charles University of Prague (Czechy), University of Lahti (Finlandia), University of Saragossa (Hiszpania), University of Evora (Portugalia), University of Viseau (Portugalia), Holar University (Islandia). W swoich badaniach koncentruje się na wykorzystaniu dziedzictwa kulturowego dla zrównoważonego rozwoju turystyki i odpowiedzialnego planowania przestrzeni turystyki, sportu i rekreacji. Uczestniczyła w kilku międzynarodowych projektach badawczych (Niemcy, Szwecja, Holandia, Wielka Brytania, Polska, Turcja); jest autorem ponad dwustu publikacji naukowych, w tym kilku monografii, tekstów opublikowanych w języku angielskim, niemieckim, polskim i serbskim; współautor kilkudziesięciu planów architektonicznych i urbanistycznych (zrealizowanych w Polsce, Niemczech, Nigerii i Libii) oraz wzorów użytkowych obiektów rekreacyjnych dla osób niepełnosprawnych - formalnie zarejestrowanych w Urzędzie Patentowym RP.

Kontakt: Akademia Wychowania Fizycznego Józefa Piłsudskiego w Warszawie;

e-mail:anna.piechotka@gmail.com

Anna Pawlikowska-Piechotka, professor, PhD Eng Arch. - architect and urban planner, in 2004-2014 a visiting professor at University College Birmingham (United Kingdom), Charles University of Prague (Czech Republic), University of Lahti (Finland), University of Saragossa (Spain), University of Evora (Portugal), University of Viseau (Portugal), Holar University (Iceland). In her research, she focuses on the usage of cultural heritage for sustainable tourism and responsible planning for tourism, sport and recreation. She participated in several international research projects (Germany, Sweden, Holland, UK, Poland, Turkey); she is the author of over two hundred scientific publications, including several monographs,papers published in English, German, Polish and Serbian; co-author of several architectural and urban plans of recreation and tourist space (commissioned in Poland, Germany, Nigeria and Libya) and utility models of recreation facilities for disabled - formally registered in the Polish Patent Office.

Contact: the Józef Piłsudski University of Physical Education in Warsaw;

e-mail:anna.piechotka@gmail.com 